\title{
FIREARMS AND FEDERAL LAW: THE GUN CONTROL ACT OF 1968
}

\author{
FRANKLIN E. ZIMRING*
}

$\mathrm{I}_{\mathrm{N}}$ 1968, after five years of debate on firearms control, Congress passed a Gun Control Act designed to "provide support to Federal, State, and local law enforcement officials in their fight against crime and violence." This paper reports on an effort to study the impact of the Gun Control Act on the problems that prompted its passage. The study is of possible interest for two reasons.

First, it is an attempt to increase our rather modest knowledge of the effects of governmental efforts to control firearms violence. In recent years the rate of gun violence in the United States has managed to grow to alarming proportions without the benefit of sustained academic attention. ${ }^{2}$ The 1968 Act-the only major change in federal policy since 1938-seems a natural place to look for clues about the effects of gun controls. And the need for knowledge in this area seems obvious, inasmuch as controversy is rampant and new federal legislative proposals are almost a weekly Washington event.

Second, the study is an effort to gain some perspective on the difficulties

* Professor of Law, and Co-Director of the Center for Studies in Criminal Justice, University of Chicago. The research reported in this article was supported by a grant from the Law and Social Science Program of the National Science Foundation, GS 38285. Data for the study were provided by the U.S. Bureau of Alcohol, Tobacco and Firearms, the Uniform Crime Reporting Branch of the Federal Bureau of Investigation (F.B.I.), and the Washington, D.C. Police Department. Without such cooperation the study could not have gone forward. Virginia Cook Aronson, Nathan Dardick, Marlene Dubas, Stanley Grimm, Theodore Hirt, and Barry Howard-all present or former University of Chicago law students-served as research assistants on this project. Mark Leff, then a doctoral candidate in history at the University of Chicago, prepared a history of federal firearms legislation that bears a striking resemblance to the materials in the first section of Part I. The views expressed in this article are, of course, my own, and do not necessarily refiect those of the individuals and agencies that have cooperated in this research.

1 Gun Control Act of 1968, § 101, Pub. L. No. 90-618, 82 Stat. 1213.

2 Between 1963 and 1973 the rate of crime homicide known to the police increased from 4.5 per 100,000 to 9.3 per 100,000 . Killings by all means other than guns increased from 2.0 per 100,000 to 3.1 per 100,000 . Gun killings increased from 2.5 per 100,000 to 6.2 per 100,000. Compare Federal Bureau of Investigation (F.B.I.), Uniform Crime Reports 1963, at 3, 6-8 with id. 1973, at 6-10. See also George D. Newton \& Franklin E. Zimring, Firearms and Violence in American Life 49-53 (Nat'l Comm'n on the Causes \& Prevention of Violence, Staff Report, 1963) for a discussion of the relationship between firearms and violent crime. 
and promise of empirical studies of "legal impact." Over the past few years, studies attempting to assess the impact of legislation have begun to occupy an important place in law-related scholarship. ${ }^{3}$ Diverse both in subject matter $^{4}$ and methodology, these studies are motivated by the hope that they will build toward a deeper understanding of law as an instrument of social control. ${ }^{5}$

The first section of this paper gives a capsule outline of the antecedents of the Gun Control Act-prior federal laws regulating firearms traffic and some of the legislative proposals that affected the shape of the 1968 law. Part II briefly analyzes the Act itself, showing how prior federal law was altered and how the alterations were thought to serve regulatory ends. Part III presents data on the impact of the law, focusing on the so-called "Saturday Night Special" ban and the effort to aid state and local gun control efforts by reducing the flow of firearms from loose-control to tightcontrol states. Part IV discusses some of the broader implications of the study.

The study will be of little use to the most fervent friends and foes of gun control legislation. It provides data they do not need. Each group has already decided that the 1968 Act has failed, and each group uses the Act's presumed failure to confirm views already strongly held. Enthusiasts for strict federal controls see the failure of the law as proof that stricter laws are needed, ${ }^{6}$ while opponents see it as evidence that no controls will work. ${ }^{7}$ The picture that emerges from available data is more equivocal. There is evidence that

3 A partial list of empirical studies of changes in law includes Vilhelm Aubert, Some Social Functions of Legislation, 10 Acta Sociologica 98 (1966); David C. Baldus, Welfare as a Loan: An Empirical Study of the Recovery of Public Assistance Payments in the United States, 25 Stan. L. Rev. 123 (1973); Donald T. Campbell, Reforms as Experiments, 24 Am. Psychologist 409 (1969); Donald T. Campbell \& H. Laurence Ross, The Connecticut Crackdown on Speeding: Time-Series Analysis Data in Quasi-Experimental Analysis, 3 L. \& Soc'y Rev. 33 (1968) ; Gene V. Glass, Analysis of Data on the Connecticut Speeding Crackdown as a Time-Series Quasi-Experiment, 3 L. \& Soc'y Rev. 55 (1968); Gene V. Glass, George C. Tiao, \& Thomas O. Maguire, The 1960 Revision of German Divorce Laws: Analysis of Data as a Time-Series Quasi-Experiment, 5 L. \& Soc'y Rev. 539 (1971); William M. Landes \& Lewis C. Solmon, Compulsory Schooling Legislation: An Economic Analysis of Law and Social Change in the Nineteenth Century, $32 \mathrm{~J}$. Econ. Hist. 54 (1972) ; H. Laurence Ross, Law, Science and Accidents: The British Road Safety Act of 1967, 2 J. Leg. Studies 1 (1973); Johan Thorsten Sellin, The Death Penalty: A Report for the Model Penal Code Project of the American Law Institute (1959).

4 Among other legislative changes studied-liberalization of divorce law in turn-of-thecentury Germany, "crackdowns" on speeding and drunk driving in the United States and Great Britain, abolition and reintroduction of the death penalty for murder, and provisions for recovering welfare payments from the estates of former recipients.

5 See Donald T. Campbell, supra note 3.

6 See, e.g., Robert Sherrill, The Saturday Night Special 19, 297 (1973).

7 See, e.g., Harold W. Glassen, Firearms Control: A Matter of Distinction, 8 Trial, January/February 1972, at 52, 54. 
the approach adopted by the Act can aid state efforts at strict firearms control, although the resources necessary to achieve this end have never been provided by Congress. There is also reason to believe that the potential impact of the Act is quite limited when measured against the problems it sought to alleviate.

\section{ORigins AND ANTECEDENTS}

While firearms have always played an important part in American life, gun control has never been an important federal legislative topic. State and local attempts to regulate the carrying of concealed weapons date from the early nineteenth century, ${ }^{8}$ with substantial legislative activity occurring during the period from 1880 through 1915, but there was no pressure generated to federalize the issue of firearms control during this time. ${ }^{9}$ In 1915 Senator Shields of Tennessee proposed a bill to ban interstate commerce in handguns, but no bill that could properly be called an effort at firearms control was reported out of a congressional committee prior to the end of World War I. ${ }^{10}$

In 1919 a 10 per cent manufacturers' excise tax on firearms was imposed as part of a larger War Revenue Act, ${ }^{11}$ and though the primary motive of the legislation was fiscal, the legislative history of the tax also reveals concern with handguns as a public safety problem. ${ }^{12}$ Like most emergency tax measures, the tax handily survived its emergency and is still, in amended form, a part of federal firearms policy..$^{13}$ The excise tax is also of lasting importance because the use of the taxing power and the vesting of regulatory responsibility in the Department of the Treasury, begun in 1919, set the pattern for later efforts at federal firearms control.

Urban crime and handgun use received an increasing amount of public attention during the post-World War I years, ${ }^{14}$ and this period produced a significant amount of state and local firearms legislation, as well as more debate about a federal role in gun regulation. By 1924, more than a dozen

8 George D. Newton \& Franklin E. Zimring, supra note 2, at 87 \& n.4.

9 Mark Leff, Federal Firearms Control Before 1920 (unpublished paper, Univ. of Chicago Law Sch., Center for Criminal Justice).

10 Hearings on H.R. 2610 and H.R. 25170 before a Subcommittee of the House Comm. on Ways and Means, 62d Cong., 2d Sess., passim. (1912); 51 Cong. Rec. 14248 (1914) (introduction of H.R. 18520 by Representative Kindel); 52 Cong. Rec. 4084 (1915) (remarks of Senator Shields).

11 Revenue Act of 1918, ch. $18 \& 900(10), 40$ Stat. 1057, 1122 (now Int. Rev. Code of 1954, \& 4181).

12 See 56 Cong. Rec. (App.) 612 (1918) (remarks of Representative Lonergan).

13 The Wildlife Restoration Act, 16 U.S.C. $\$ 669$ (b) (1970) earmarks receipts from the tax to state wild-life preservation programs.

14 Lamar T. Beman, comp., Outlawing the Pistol (1926), passim. 
federal firearms control bills, most of them regulating interstate commerce in handguns, were before Congress. ${ }^{15}$

In 1927 Congress enacted a law prohibiting the mailing of concealable firearms to private individuals. ${ }^{16}$ Directed against the undermining of state and municipal firearms control statutes through out-of-state handgun sources, this law represented the first federal attack on "mail order murder." As an attempt to curtail interstate movement of handguns, the 1927 prohibition (which remained in effect until 1968) was deficient. Of all interstate carriers, only the United States mails were closed to handgun commerce. This partial closure was of little effect, since guns could be ordered by mail and delivered to the purchaser by private express companies. ${ }^{17}$ Nevertheless, the effort was an important precedent for control of interstate firearms traffic in two respects. The 1927 law and dissatisfaction with its effectiveness led to proposals for tighter controls on interstate firearms sales to private citizens that culminated in the Gun Control Act of 1968's near-total ban on such transactions. And by distinguishing between dealers (who were allowed to receive concealable firearms) and other private citizens (who were not), the postal ban created some incentive for private citizens to be considered dealers and thus created the need to define the limits of the dealer category. ${ }^{18}$ This problem was not important in the years immediately after 1927 because there were so many other ways for private citizens to circumvent the postal ban. But as succeeding generations of federal legislation made the status of "dealer" more attractive, they also made it necessary for any effective scheme of federal regulation to define, license, and regulate firearms dealers. ${ }^{19}$

It is easy to overestimate the public importance of firearms regulation during this period. While crime and criminals were major issues, there is little evidence that the "gun problem" and proposals to increase the federal role in firearms regulation were visible public issues. ${ }^{20}$ The major public concern was crime control, and guns were perceived as one small part of that larger issue. There is also little to suggest that there was strong sentiment prior to the early New Deal period to think of crime control as a national problem meriting substantial federal regulation.

The focus of discussion during the 1920 s was on uniform state laws regulating possession and use of handguns. In 1923 a draft of a uniform revolver

\footnotetext{
1565 Cong. Rec. (Index) 140, 295 (1924).

16 Act of June 25, 1948, $\$ 1715,62$ Stat. 781 (codified at 18 U.S.C. $\$ 1715$ (1970)).

17 See Interstate Traffic in Mail-Order Firearms, hearings before the Subcomm. to Investigate Juvenile Delinquency of the Senate Comm. on the Judiciary, 88th Cong., 1st Sess., pt. 14, at 3186 (1963).

18 Act of June $25,1948, \S 1715,62$ Stat. 781 (codified at 18 U.S.C. $\$ 1715$ (1970)).

19 See notes 30 (Federal Firearms Act) and 89 (Gun Control Act of 1968), infra.

20 Nat'l Conf. of Comm's on Uniform State Laws, Handbook and Proceedings 1923, at 20.
} 
law (prepared by the United States Revolver Association which hoped to preempt what it considered to be irresponsible permit schemes) was submitted to the National Conference of Commissioners on Uniform State Laws. ${ }^{21}$ This proposal served as the model for the Conference's 1926 proposed Uniform Firearms Act, which established license requirements for handgun dealers, a 48-hour waiting period prior to handgun purchase, and the registration of handguns purchased from dealers and supplementary penalties for handgun use in violent crimes. ${ }^{22}$

In 1927 the first National Crime Commission recommended a more stringent uniform state law as the primary national handgun policy, with supplementary federal legislation designed to forbid the importation of handguns and machine guns, and an extension of the ban on interstate shipment of handguns to cover common carriers. ${ }^{23}$

The first serious discussion of a more extensive federal role in firearms regulation came in the early years of the New Deal. By 1932 federal solutions to many problems were being advocated with increasing frequency. ${ }^{24}$ Public concern with crime and criminals had shifted from worry about the "highwaymen" or "thugs" to the machine-gun-toting interstate gangster personified by John Dillinger. ${ }^{25}$ The national fear of gangsters combined with the Roosevelt Administration's willingness to stretch the limits of federal jurisdiction to produce an unprecedented package of federal anticrime initiatives, resulting in a bumper 1934 crop of laws creating, among others, the federal crimes of robbing a federally insured bank, assault of a federal agent, and interstate flight to avoid prosecution for certain state felonies. ${ }^{26}$

There were a number of reasons why a federal firearms control proposal could be expected as part of a larger crime-control effort. The submachine gun, then of public importance, was a natural candidate for public fear and legislative wrath. It is also worth noting that Franklin D. Roosevelt as Governor of New York had defended that state's restrictive handgun licensing statute, had campaigned for a state ban on machine guns, and had publicly advocated federal regulation of interstate commerce in handguns. ${ }^{27}$

21 Uniform Firearms Act $\S 11$, in id. 1926, at 577 .

22 Id. 1927 , at 890.

23 John Brabner-Smith, Firearm Regulation, 1 Law \& Contemp. Prob. 400 (1934); Drastic Law Aimed at Pistols, N.Y. Times, Feb. 23, 1927, at 25.

24 See generally, Arthur M. Schlesinger, Jr., The Age of Roosevelt, vol. 2, The Coming of the New Deal (1958).

25 William J. Helmer, The Gun That Made the Twenties Roar, 114-16 (1969).

26 Roosevelt Opens Attack on Crime, Signing Six Bills as Challenge, N.Y. Times, May 19, 1934, at 1; 3 The Public Papers of Franklin D. Roosevelt 242-45 (Samuel I. Rosenman ed. 1938).

27 Roosevelt Cites Own Case to Show Gun Permit Dangers, N.Y. Times, Sept. 3, 1931, at 8; Governor Vetoes Law Changes, N.Y. Times, March 29, 1932, at 4. 
But the principal booster for a federal role in firearms control was Roosevelt's first Attorney General, Homer Cummings. It was his Justice Department that was the moving force behind the National Firearms Act of $1934,{ }^{28}$ and that attached a provision for federal registration of all handguns to the "anti-machine gun" measure sent to Congress in $1934 .{ }^{29}$ When the handgun registration segment of the bill was deleted in the House, the Justice Department continued to introduce handgun registration proposals, and to fight for them throughout the 1930s, long after crime control had lost its place in the hierarchy of New Deal legislative goals.

The firearms control campaign of the 1930s resulted in two pieces of federal legislation: the National Firearms Act of $1934,{ }^{30}$ and the Federal Firearms Act of $1938 . .^{31}$ Neither law reflected the scope of Attorney General Cummings' ambitions, but the two acts established a role for the federal government in firearms control, and these laws were the immediate precursors of the Gun Control Act of 1968 .

The National Firearms Act of 1934, after the handgun registration provisions were deleted, was a concentrated attack on civilian ownership of machine guns, sawed-off shotguns, silencers, and other relatively rare firearms that had acquired reputations as gangster weapons during the years preceding its passage. Modeled on the Harrison Narcotics Act, ${ }^{32}$ the N.F.A. based its regulatory powers on a tax imposed on traffic in the weapons, thus generating federal jurisdiction for intrastate as well as interstate transactions. The tax rate, $\$ 200$ per transfer, did not seem calculated to encourage extensive commerce in these weapons. ${ }^{33}$ The Act also provided for the immediate registration of all covered weapons, even if illegally owned-a provision altered in 1968, after the United States Supreme Court held the 1934 provision to be an infringement on the constitutional privilege against selfincrimination. . $^{\mathbf{4}}$

28 Hearings on H.R. 9066 before the House Committee on Ways and Means, 73d Cong., 2d Sess., at 4, 65, and 130 (1934).

29 Even when the bill included handgun registration, it was popularly known as an "anti-machine gun" law. See Cummings Asks Airplanes, N.Y. Times, April 25, 1934, at 3.

80 National Firearms Act, ch. 757, 48 Stat. 1236 (1934), as amended by Int. Rev. Code of 1954, $\$ \$ 5801-5872$.

31 Federal Firearms Act, ch. 850, 52 Stat. 1250 (1938) (repealed by Pub. L. No. 90-351, 8 906, 82 Stat. 234 (1968)).

32 Harrison Act, Int. Rev. Code of 1954, $\$ 4701$ et seq. (repealed by Pub. L. No. 91-513, $\$ 1101$ (b) (3) (a), 84 Stat. 1292 (1970)).

33 Governmentally owned weapons were exempt from the tax and constituted the bulk of all registered weapons. See U.S. Int. Rev. Service (I.R.S.), Annual Report of the Comm'ner 1941, at 29.

84 Haynes v. United States, 390 U.S. 85 (1968). Two companion cases, Marchetti v. United States, 390 U.S. 39 (1968), and Grosso v. United States, 390 U.S. 62 (1968), struck down convictions based on failure to register and report as gamblers under 
There are two respects in which the National Firearms Act influenced the shape of the 1968 gun-control effort. First, the N.F.A. put the government in the business of licensing manufacturers and dealers of firearms, although the number of weapons and dealers affected was relatively small. Second, the use of the taxing power again centered enforcement responsibility in the Department of the Treasury. ${ }^{35}$

The N.F.A. is often cited as an instance in which federal firearms controls succeeded in substantially achieving their purpose-in this case the extinction of the submachine gun and other gangster weapons. ${ }^{36}$ On this issue the historical record is not completely clear. To be sure, the number of frightening incidents involving submachine guns diminished after the N.F.A. and a coordinated federal effort to halt production of the guns. ${ }^{37}$ This was also a period of intensive state effort at submachine gun control. The dangers of drawing a causal inference between federal regulation and the end of the "Tommy-Gun Era" are, however, manifold. Available data on the use of gangster weapons before the N.F.A. are not precise; thus a meaningful before-and-after study is difficult. More important, it is hard to determine whether the use of these weapons was a phenomenon that had reached an unnatural peak just before the advent of federal regulation and would have abated in any event.

The Federal Firearms Act of $1938^{38}$ was the most significant pre-1968 attempt to impose federal controls on the commerce and possession of a broad spectrum of firearms. Shepherded through the Congress by the $\mathrm{Na}$ tional Rifle Association, the 1938 Act was pressed more to submerge than to further the schemes for federal handgun registration that regularly commuted from the Justice Department to the Congress (and back) during the 1930 s. $^{39}$

Int. Rev. Code of 1954 , $\S$ 4401-4423. In all three cases the constitutional flaw was that registration and reporting would show the registrant to be violating state or federal law. The N.F.A. amendments in 1968 provide that registration information may not be used in a criminal prosecution.

35 National Firearms Act, ch. 757, 88 5801, 5811, 5821, 48 Stat. 1236 (1934), as amended Int. Rev. Code of $1954, \S \S 5801,5811,5821$.

86 William J. Helmer, supra note 25 , at $152-53$.

37 Id. at $144-45$.

38 Federal Firearms Act, ch. 850, 52 Stat. 1250 (1938) (repealed by Pub. L. No. 90-351, \& 906, 82 Stat. 234 (1968)).

39 The origin of the Federal Firearms Act of 1938 was S. 3, 74th Cong., 1st Sess. (1935), introduced by Sen. Copeland of New York in 1935 and reportedly drafted by the Senator's staff, a representative of the Justice Department, and a representative of the National Rifle Association. See 79 Cong. Rec. 11973 (1935) (remarks of Sen. Copeland). Watching this bill's progress unenthusiastically, the Justice Department continued its campaign for firearms registration, eliciting some favorable editorial response, but little congressional support. Homer Cummings to Robert L. Doughton, with attached editorials, April 11, 1938, Folder 708, Robert L. Doughton Papers in the Southern His- 
The 1938 Federal Firearms Act spread a thin coat of regulation over all firearms and many classes of ammunition suitable for handguns. All manufacturers, importers and dealers handling guns shipped in interstate commerce were required to obtain federal licenses ( $\$ 25$ for manufacturers and importers, $\$ 1$ for dealers)..$^{40}$ Licensees were prohibited from knowingly shipping a firearm in interstate commerce to some felons, a fugitive from justice, a person under indictment, or anyone required to have a license under the law of the seller's state who did not have a license. ${ }^{41}$ All these prohibited owner classes were also forbidden to receive guns which were or had been in interstate commerce. Dealers were also required to keep records of firearms transactions. Enforcement responsibility was vested in the Secretary of the Treasury, who delegated the assignment to the Internal Revenue Service. ${ }^{42}$

The apparent aims of the 1938 legislation were to create an independent federal policy banning the receipt of firearms by what must have been thought of as the criminal class of society, and to aid state and local efforts at tighter control by prohibiting transactions that would violate local laws. As a strategy to accomplish these goals, however, the Federal Firearms Act was deficient in a number of respects, and further crippled by a tradition of less-than-Draconian enforcement by the Internal Revenue Service. One major problem was that the Act prohibited only the transfer of weapons to the prohibited classes when the transferor knew or had reasonable cause to believe his transferee was a felon, fugitive, etc., ${ }^{43}$ but transferors were not required to obtain positive identification of their customers or to take other steps to verify the eligibility of customers under the act. From the standpoint of prosecuting dealers for violation of the federal ban against sale to felons, the requirement of knowledge, coupled with the absence of a verification system, rendered the Act stillborn. When local law required a license, however, the license requirement made both dealer and customer liable under federal law if they were aware of the local requirements.

Two other prominent loopholes in the 1938 Act deserve special mention because they determined the shape of the 1968 Act. First, the modest cost of a dealer's license and the fact that dealers could freely receive firearms in interstate commerce created strong incentives for private parties to receive

torical Collection at the University of North Carolina Library, Chapel Hill, North Carolina. The N.R.A. predicted that "The passage of this measure [the F.F.A.] would mean the death of the Attorney General's bills." See Carl Bakal, the Right to Bear Arms 177 (1966).

40 Federal Firearms Act, ch. 850, \& 3(a), 52 Stat. 1251 (1938).

41 Federal Firearms Act, ch. 850, $\$ \$ 2$ (c)-2(d), 52 Stat. 1250-51 (1938).

42 Federal Firearms Act, ch. 850, $\$ 7,52$ Stat. 1252 (1938); T.D. 4834, 1938-2 Cum. Bull. $465,467$.

43 Robert Sherrill asserts that the first arrest of a dealer under this section was made in 1968. Robert Sherrill, supra note 6 , at 66 . 
dealer licenses. This in turn resulted in a large number of dealers (over $100,000$ in the mid-1960s $)^{44}$ and made any serious effort to monitor dealer compliance with the act an enormous undertaking for an Internal Revenue Service that did not, in any event, give the F.F.A. a very high priority. A second problem was that customers from states that required licenses could purchase guns in states that did not, as long as they did not give the dealer in the no-license state any reason to have knowledge of their lack of eligibility. The customer might have to lie to his supplier and would himself be subject to federal criminal penalties, but guns were readily available through this route. ${ }^{45}$

The Commissioner of Internal Revenue had been designated by the Secretary of the Treasury to promulgate regulations to facilitate the enforcement of the Act, but the regulations governing administration of the F.F.A.6 fell far short of the powers delegated by Congress. Under the act, dealers were required to maintain "permanent records"47 of firearms transactions; under the regulations in effect until 1958 records had to be maintained for six years (ten years after 1958), ${ }^{48}$ and there was very little effective policing of dealer compliance with the record-keeping provisions. ${ }^{49}$ The F.F.A. regulations did not require serial numbers on firearms (necessary to identify a particular gun as having been the subject of a transaction) until 1958, and then exempted .22-caliber rifles from the serial number requirement. More significantly, no attempt was made to end by regulation the immunity from prosecution enjoyed by dealers because they did not have to verify the eligibility of their customers. While it was probably beyond the rule-making power delegated by the Act to impose a waiting period or the compulsory notification of police departments as to firearms transactions, it could easily have been considered within the Commissioner's authority to require transferees to positively identify themselves.50 Indeed, it is a fascinating exercise to debate how many of the changes brought about by the Gun Control Act of 1968 could have been accomplished by rule-making power under the Federal Firearms Act of 1938 and other prior federal laws. ${ }^{51}$

44 Federal Firearms Act [II], hearings on S. 1 before the Subcomm. to Investigate Juvenile Delinquency of the Senate Comm. On the Judiciary, 90th Cong., 1st Sess., at 40 (1967).

45 Mail order advertisements for guns contained forms for the prospective customer to sign, relieving the dealer of liability under the Act. See Interstate Traffic in Mail Order Firearms, supre note 17, pt. 14, at 3231 .

46 Treas. Reg. 8 315.0-315.14, T.D. 4898, 1939-1 Cum. Bull. 364.

47 Federal Firearms Act, ch. 850, \& 3(d), 52 Stat. 1252 (1938).

48 Treas. Reg. $\$ 315.10$ (c), T.D. 4898, 1939-1 Cum. Bull. 370.

49 Treas. Reg. 8177.53 (1958).

50 Federal Firearms Act, ch. 850, \& 7, 52 Stat. 1252 (1938).

$61 \mathrm{My}$ own view is that form 4473 and other provisions of the 1968 dealer regulations 
Few resources were invested in the enforcement of the Federal Firearms Act. In 1967 the Alcohol, Tobacco and Firearms division of the Internal Revenue Service reported an investment of 35 man-years in enforcing both the National Firearms Act of 1934 and the Federal Firearms Act of $1938 .^{\mathbf{6 2}}$ During the period 1966-1968, a total of 275 arrests were reported under the Federal Firearms Act, and it has been asserted that no dealers were charged with violating the Act until 1968. ${ }^{\text {.3 }}$

The lack of aggressive enforcement may obscure a deeper reason for the failure of the F.F.A.: the tasks of keeping firearms out of the hands of a small criminal class and keeping firearms from crossing those state lines where they are unwelcome was an excruciatingly difficult job in a country that averaged more than one gun per household ${ }^{54}$ during the career of the F.F.A. Strict regulation of gun dealers could have done part of the job, but would have required enormous federal effort, particularly since the great majority of all states did not require licenses of gun purchasers. ${ }^{55}$ And even if all dealers were regulated, about half of all guns are acquired used in the United States, and more than half of these guns are acquired from private individuals. ${ }^{56}$ The only way to attempt to control this secondary or handto-hand market would be the registration of firearms in order to reduce the hand-to-hand "float" of guns from eligible to ineligible owners. states had handgun registration during the life of the F.F.A., ${ }^{58}$ and no state required the registration of all weapons. ${ }^{50}$

This is not to say that the Federal Firearms Act was useless, or that more energetic enforcement would not have made some impact on the problems created by the criminal use of firearms. The F.F.A. provided an additional charge that could be lodged against a suspect arrested by authorities for another offense and found in possession of a gun he was prohibited from acquiring; even after the presumption that such a gun had been in interstate

could have been accomplished by regulation, while the ban on sales to nonresidents and minors could only have been accomplished by legislation. However, while regulation could not have prohibited sales to nonresidents, the Service might have required special identification procedures and, perhaps, notification of local law enforcement officials in the transferee's state.

62 Federal Firearms Act [II], supra note 44, at 75. In 1965, the Treasury Department had testified that it had assigned only five-workers in its national office to devote full time to these enforcement duties. See 26 Cong. Q. Weekly Rep. 809 (1968).

63 Robert Sherrill, supra note 6, at 66.

64 George D. Newton \& Franklin E. Zimring, supra note 2, at 6.

55 Id. at 89 .

56 Id. at 13 .

57 Id. at 83 .

68 George D. Newton \& Franklin E. Zimring, supra note 2, at 89; see also id. at 201-40 (App. G).

68 Ibid. 
commerce after the F.F.A. became effective was struck down, ${ }^{80}$ it was often possible to trace the commercial history of the particular gun and file federal firearms charges against a defendant in lieu of or in addition to the offense for which he was arrested. ${ }^{61}$ The law also could be and was used as a tool to generate criminal liability for a convicted felon who had come to the special attention of federal authorities for other reasons-in much the same fashion that Al Capone's income tax, rather than the origins of his income, proved his undoing. ${ }^{62}$

Although Homer Cummings was disappointed, the record seems to indicate that Congress got pretty much what it wanted in the F.F.A.: a symbolic denunciation of firearms in the hands of criminals, coupled with an inexpensive and ineffective regulatory scheme that did not inconvenience the American firearms industry or its customers. The Justice Department continued to recommend more extensive firearms legislation for a few years, ${ }^{63}$ but the Department's emphasis on such proposals faded after Cummings' departure in 1939. Whatever the faults of the F.F.A. as a regulatory scheme, they went unnoticed in a nation where violent crime rates had been declining since the mid-1930s, and the larger issues of war and economic recovery preoccupied public attention.

The period from 1939 (when the initial regulations under the F.F.A. were issued) through 1957 (when new regulations were proposed) was almost completely uneventful in relation to federal firearms control. There was also very little legislative activity on the state and local level.

In 1957 the Commissioner of Internal Revenue proposed a number of changes in the regulations governing the manufacture and sale of firearms

60 United States v. Tot, 131 F.2d 261 (3d Cir. 1942).

61 The minimum conditions for tracing a gun are:

(1) determination of the manufacturer;

(2) serial number;

(3) that the manufacturer keep records as required by the F.F.A.

It is not necessary in the prosecution of a felon to prove how or when he acquired the weapon if the weapon was first sold after 1968. Gun Control Act of 1968, § 105(a), 82 Stat. 1226. For discussion of the F.F.A. provisions see United States v. Tot, 131 F.2d 261, 270 (3d Cir. 1942).

62 Mark Leff, supra note 9, at 13. See also John Brabner-Smith, supra note 23, at 402 ; Homer Cummings October 5, 1937, Speech, in Selected Papers at 86 (Carl Brent ed., 1939) ; Herbert Corey, Farewell, Mr. Gangster !, at 133 (1936).

${ }^{63}$ Pistol Control Sought, N.Y. Times, Jan. 12, 1936, \& 4, at 11; U.S. Dep't of Justice, Annual Report of the Att'y Gen'l 1935, Jan. 4, 1936 message, at 2. See also Jan. 6, 1937 message in id. 1936, at 3; Jan. 3, 1938 message in id. 1937, at 9-10; December 31, 1938 message in id. 1938, at 8; Jan. 3, 1940 message in id. 1939, at 9; Jan. 3, 1941 message in id. 1940, at $13 ; 1947$ message in id. 1946, at 28. Attorney-General Cummings' Jan. 5, 1934, message to Congress (in id. 1933, at 1) also recommended firearms registration. Thus the Jan. 5, 1935 message was the only one in F.D.R.'s first two terms that failed to deal with this issue. 
under the F.F.A., including a serial number requirement for all firearms, a rule requiring that "permanent" dealer-records be maintained permanently rather than the six years provided in the earlier regulations, and a series of changes in the type of records that dealers were required to keep. ${ }^{64}$ The proposals encountered stiff opposition from industry and gun-user groups, and the regulations adopted in 1958 were somewhat less ambitious: the record requirement was set at ten years, and serial numbers were required for all frearms except .22-caliber rifles. ${ }^{65}$ More important than the details of these regulations was the continued low profile maintained by the Internal Revenue Service in the enforcement of the Act, and the lack of any evident pressure on the Service or on the Congress for more stringent controls. While rates of violence remained high in the United States in comparison with other western industrial countries, violent crime rates were at far lower levels than had been experienced in the 1920s and '30s, and the public fear of crime had diminished to levels that, in hindsight, symbolized domestic tranquility.

The first indication that a further federal role in firearms regulation might come, and the first modern origin of the Gun Control Act of 1968, was the increase in inexpensive imported firearms, largely military surplus, that started to make serious inroads into the United States market in the mid1950s. In 1955 domestic manufacturers produced 556,000 rifles for the United States civilian market, and only 15,000 rifles were imported into this country for domestic sale; ${ }^{66}$ by 1958 the number of rifles imported into the United States had increased to 200,000 , whereas domestic production had fallen to $405,000 .^{67}$

In 1958 Senator John F. Kennedy of Massachusetts, a gun-producing state, proposed a bill to prohibit "the importation of firearms originally manufactured for military purposes." 38 This frankly protectionist bill did not pass, but the Congress did prohibit the re-importation of those weapons that the United States had sent abroad under its foreign-assistance act. ${ }^{69}$

Foreign handguns, both military surplus and new production, began to make some impact on the United States market during the same period. In 1955, about 67,000 handguns were imported for sale to United States civilians. By 1959 annual imports were 130,000 ; by 1966 the figure rose to 500,000 ; and by 1968 unit volume of imported handguns had exceeded the million mark. ${ }^{70}$ The inexpensive, low-caliber, new-production handguns that com-

04 George D. Newton \& Franklin E. Zimring, supra note 2, at 101-02.

65 Id. at 102.

66 Id. at 172-73 (Tables C-1 and C-2).

67 lbid.

68 S. 3714, 85th Cong., 2d Sess. (1958).

69 Mutual Security Act of 1958, \& 403(k), 22 U.S.C. $\$ 1934$ (b) (1970).

70 George D. Newton \& Franklin E. Zimring, supra note 2, at 173 (Table C-2). 
prised the bulk of United States imports by the mid-1950s did not present the same type of direct competition to established American firms as the rifle imports of the 1950s-domestic handguns were thought to be of higher quality, and the civilian handgun market was growing quickly enough after 1965 to accommodate substantial increases in both domestic and imported weapons. ${ }^{71}$ Yet the imported handgun was a specially vulnerable weapon to legislative attack, because it was cheap and thus available to a broader spectrum of the population, it was without the redeeming social virtue of a law enforcement or sporting use, and the importers of such weapons had far less political influence than domestic manufacturers. ${ }^{72}$

Some observers have suggested a direct connection between the increase in gun imports and the renewal of congressional interest in the easy availability of guns in the United States, ${ }^{73}$ but the evidence on this is spotty. ${ }^{74}$ When Senator Thomas Dodd of Connecticut (a major gun-producing state) became chairman of the Senate Subcommittee on Juvenile Delinquency in 1961, he "directed the staff of the Subcommittee to initiate a full-scale inquiry into the interstate mail order gun problem."75 During 1961-1962 staff studies of mail order guns sold to residents of the District of Columbia and several states provided evidence that "criminals, immature juveniles, and other irresponsible persons were using the relative secrecy of the mail order-common carrier method of obtaining firearms, because they could not purchase guns under the laws in their own jurisdictions."76

Armed with these studies, the Dodd Committee conducted hearings in 1963 that sought to draw public attention to Dodd's proposal to prohibit the sale of handguns by mail order to persons under eighteen, and require a notarized affidavit to be submitted with handgun mail orders stating that the customer was old enough to purchase the gun and otherwise legally entitled to receive it. ${ }^{77}$ The emphasis in these hearings was on the mail order mechanism, juveniles and felons as purchasers, and "the cheap products which are so fre-

71 Id. See also id. at 18, 20.

72 Federal Firearms Act [II], supra note 44, at 975.

73 Richard Harris, Annals of Legislation: If You Love Your Guns, New Yorker, April 20, 1968, at 57; Robert Sherrill, supra note 6, at 92-93.

74 While the representative of the National Shooting Sports Foundation, an industry group, was not displeased with the Dodd handgun proposal, there is no firm evidence that the proposed ban on mail-order weapons would itself represent any protection to domestic manufacturers. The later marriage of importation bans with proposals to strengthen controls of interstate sales does not establish that the controls were simply a front for protectionist legislation.

75 Thomas Dodd, Federal Firearms Legislation, 1961-1968, at 3 (unpublished report prepared for the Subcomm. to Investigate Juvenile Delinquency of the S. Comm. on the Judiciary, 90th Cong., 2d Sess., 1968).

76 Id. at 10.

77 This proposal became S. 1975, introduced August 2, 1963, 87th Cong., 1st Sess. 
quently sold via mail order."78 The bill was drafted with Department of the Treasury help, and received support from an industry spokesman at the 1963 hearings. ${ }^{79}$

Five days after the assassination of John F. Kennedy, Senator Dodd amended his bill to cover mail order traffic in shotguns and rifles. ${ }^{80}$ The bill died in the Senate Commerce Committee in $1964,{ }^{81}$ but the forces leading to the adoption of the Gun Control Act of 1968 were already at work.

In March of 1965, President Johnson sent Congress a message on crime that requested an extension of the federal role in firearms regulation. ${ }^{82}$ The administration proposal, introduced as Senate Bill 1592, had been drafted by the Treasury staff with support from the Department of Justice. ${ }^{83}$ The bill contained most of the key strategic elements of the Gun Control Act of 1968: increases in the fees and regulation of firearms dealers; a federal minimum age requirement for handgun (21) and long gun (18) purchase; and a prohibition of handgun sales to residents of another state. The bill was not referred out of committee. ${ }^{84}$

In January 1967 a similar bill was introduced by Senator Dodd and later amended to conform to the administration proposal forwarded that February.$^{85}$ The bill was referred to the Judiciary Committee, the parent committee of Dodd's Subcommittee on Juvenile Delinquency. In April 1968, after failing to support the administration proposal, the Judiciary Committee reported out a bill modeled on the President's proposal but limiting the ban on sales to citizens of another state to handguns. ${ }^{86}$ This bill became Title IV of the Omnibus Crime Control Act of 1968, passed by the Senate in May 1968 and by the House on June 6, the day after the shooting of Robert F. Kennedy. ${ }^{87}$

\footnotetext{
78 Interstate Traffic in Mail Order Firearms, supra note 17, pt. 14, at 3497 (1963) (testimony of Howard Carter, Jr., Member, Board of Governors, National Shooting Sports Foundation).

79 Id. at 3498 .

80 Thomas Dodd, supra note 74, at 13 .

81 Id. at 55.

82 H.R. Doc. No. 103, 89th Cong., 1st Sess. (1965), 111 Cong. Rec. 4278 (1965).

83 S. 1592, 89th Cong., 1st Sess. (1965).

84 Thomas Dodd, supra note 74, at 26-27. A milder proposal, S. 3767, was reported out of committee and the committee report discussed S. 1592 as well. Senator Dodd asserted that supporters of his bill were planning to introduce S. 1592 as an amendment to S. 3767, but that S. 3767 was never brought up for debate. Id. at 24, 27.

85 S. 1 (90th Cong., 1st Sess.) introduced Jan. 11, 1967, and evidently an early draft of the Johnson Administration gun proposal; and S. 1 Amendment 90 (90th Cong., 1st Sess.), the Administration's redrafted proposal. See Federal Firearms Act [II], supra note 44 , at 37.

86 S. Rep. No. 1097, 90th Cong, 2d Sess. (1968).

87 Passed the Senate May 24, 1968, 114 Cong. Rec. 14889 (1968); passed the House June 6, 1968, 114 Cong. Rec. 16300 (1968).
} 
In the aftermath of the Robert Kennedy assassination, a number of new firearms control measures were introduced, and the proposal to ban interstate sales of long guns received new support. In October 1968 a revised Gun Control Act was signed by the President.

During the debates on the Gun Control Act and its predecessors, two other strategies of federal gun control were widely discussed. One was the creation of federal jurisdiction and mandatory prison sentences for violent crimes committed with guns. ${ }^{88}$ This type of proposal was generally offered as an alternative to stricter controls on gun traffic by legislators generally opposed to gun-control laws. It received at least symbolic approval in the Gun Control Act's provision for additional penalties when crimes which are federal felonies are committed with guns. ${ }^{80}$ A second approach widely discussed after the Robert Kennedy assassination was for some system of federal firearms owner registration or licensing. ${ }^{90}$

The Gun Control Act of 1968, like its 1938 ancestor, was thus something of a compromise candidate at the time of its passage-representing concessions on the part of those opposed to any further federal controls and those who desired extensive further federal involvement. The primary goal of the statute, federal assistance to state efforts at control, was not the chief aim of its sponsors nor the principal fear of its opponents.

There are other parallels between the processes leading to the 1938 and 1968 Acts. In each case, administrative concern, spearheaded by the Justice Department, provided a necessary, if not a sufficient, backdrop for congressional action. ${ }^{91}$ And the symbolism of gun control seemed more important to the vast majority of Congress than the specifics of regulation. Finally, the gun control issue remained a relatively unimportant one for the Congress. No serious effort was made to oversee or evaluate the administration of the Act. ${ }^{92}$ No committee of Congress maintained any special competence in the substantive issue of federal gun regulation.93

The links between domestic violence during the 1960s and the 1968 Act are important but susceptible to overstatement. The John Kennedy assassina-

88 H.R. 11427, 89th Cong., 2d Sess. (1966).

89 Gun Control Act of 1968, 18 U.S.C. \& 924(c) (1970).

${ }^{80}$ The major bills and their sponsors: S. 3691, introduced by Dodd and supported by the President; S. 3637, Brooke; S. 3634, Tydings; H.R. 18628, Rosenthal, 90th Cong., 2d Sess. (1968).

91 See text accompanying notes 24 through 39 supra.

82 Since Senator Dodd left his subcommittee chairmanship, two sets of hearings have been held in Congress on substantive gun control matters. The Senate Subcommittee held hearings in 1971 on the "domestic Saturday Night Special." The House Judiciary Committee, Subcommittee No. 5, held hearings in June of 1972 to consider a number of firearm control proposals, including one by then Chairman Celler.

93 The senior staff of the Senate Subcommittee on Juvenile Delinquency left shortly after Thomas Dodd left the Senate. Since then, I know of no staff-study relating to gun control on Capitol Hill. 
tion helped focus attention on the ready availability of mail-order guns; the Martin Luther King and Robert Kennedy killings put pressure on Congress at crucial points in the legislative career of the Act, just as the escape from jail of John Dillinger had expedited the passage of the National Firearms Act of 1934. But the basic approach of the 1968 Act had been worked out by the Treasury Department in 1965. And the only legislative initiatives produced by the Robert Kennedy shooting, a series of proposals for a national strategy of licensing gun owners, did not affect the shape of the 1968 Act.

If the violence of the mid-1960s had little impact on the provisions of the Gun Control Act, it had a profound effect on the problems that the act addressed. Urban riots during the period 1964-1968 and increased fear of crime had a manifold impact on the quality of American urban life. One consequence of this increasing turmoil and fear was an increased demand for firearms as instruments of self-defense, particularly in big cities. Handgun sales, the best index of demand for urban self-defense weapons, averaged 600,000 a year during the first four years of the $1960 \mathrm{~s}$; by 1966 the market for handguns had doubled to 1.2 million; by 1968 the market had almost doubled again, to an estimated 2.4 million, although this figure may have been abnormally high because importers and private citizens were rushing to purchase imported handguns before the import restrictions in the 1968 act came into effect. ${ }^{94}$ The increase in urban gun ownership was paralleled by an increase in urban gun violence. Perhaps the most spectacular case study of gun violence was the city of Detroit. In 1965 Detroit experienced a total of 140 homicides; 55 of these, or 39 per cent, were committed with guns. Three years later 72 per cent of Detroit's 389 killings were committed with guns. ${ }^{95}$ The increase in gun violence in other urban areas, though less pronounced, was steady and substantial: during the period 1964-1968, gun homicide in the United States had increased 89 per cent, while homicide by all other means had increased 22 per cent. ${ }^{96}$ By 1969 a simple majority of homicides in major urban areas were committed with handguns, ${ }^{97}$ and the interstate flow of handguns into cities with restrictive state and local controls was greater than at any other time since the $1930 \mathrm{~s}^{88}$

\section{The Ends and Means of the Gun Control Act}

The Gun Control Act signed by President Johnson on October 22, 1968, was an omnibus measure reflecting a variety of congressional purposes.

\footnotetext{
94 George D. Newton \& Franklin E. Zimring, supra note 2, at 172-73. $95 \mathrm{Id}$. at 74.

96 F.B.I., Uniform Crime Reports, 1964, at 104 (1964); id. 1968, at 108.

97 Data supplied by F.B.I., Uniform Crime Reports, 1969, at 7; see Figure 2 infra. 88 See Figures 5 and 6 infra.
} 
Included in the Act were amendments to the National Firearms Act of 1934, extending its coverage and relatively prohibitive tax to "destructive devices" (bombs, hand grenades, land mines, and similar mechanisms) and altering the registration provisions of the N.F.A. to rescue its registration requirement from a successful 1968 constitutional challenge. ${ }^{99}$ The Act also mandated additional penalties for persons convicted of committing federal crimes with firearms. ${ }^{100}$ But the major objectives of the Act were three:

(1) Eliminating the interstate traffic in firearms and ammunition that had previously frustrated state and local efforts to license, register, or restrict ownership of guns.

(2) Denying access to firearms to certain congressionally defined groups, including minors, convicted felons, and persons who had been adjudicated as mental defectives or committed to mental institutions.

(3) Ending the importation of all surplus military firearms and all other guns unless certified by the Secretary of the Treasury as "particularly suitable for . . . sporting purposes."101

The centerpiece of the new regulatory scheme was the ban on interstate shipments to or from persons who do not possess federal licenses as dealers, manufacturers, importers or collectors, coupled with the declaration that it was unlawful for any person other than a federal-license holder to engage in the business of manufacturing or dealing in firearms, whether or not such a business involves interstate commerce. ${ }^{102}$ The Act thus granted federal licensees a monopoly on interstate transactions and required a federal license to engage in any but isolated intrastate transactions.

While private citizens were to be excluded from commerce in guns, federally licensed dealers were to be much more strenuously regulated. The fees for all federal licenses were increased (the dealer license from $\$ 1$ to $\$ 10$ ), ${ }^{103}$ minimum standards for licensees were set, ${ }^{104}$ and the Secretary of the Treasury was given broad powers to establish mechanisms for regulating licensed manufacturers and dealers. ${ }^{105}$

Having established federal regulation of those in the business of making, selling and importing firearms, as well as all interstate aspects of commerce in firearms, the Act pursued its major aims with a series of criminal prohibitions.

\footnotetext{
89 National Firearms Act, Int. Rev. Code of 1954, \& 5848.

100 Gun Control Act of 1968, 18 U.S.C. $\$ 924$ (c) (1970).

101 Gun Control Act of 1968, 18 U.S.C. § 925(d) (3) (1970).

102 Gun Control Act of 1968, 18 U.S.C. \& 922 (a) (1970).

103 Gun Control Act of 1968, 18 U.S.C. \& $923(\mathrm{a})(3)(\mathrm{C})$ (1970).

104 Gun Control Act of 1968, 18 U.S.C. \& 923(d) (1970).

105 Gun Control Act of 1968, 18 U.S.C. \& 926 (1970).
} 


\section{A. State Aid}

To effectuate the state aid goals of the Act, all nonlicensees were prohibited from shipping guns to other private parties in another state and from transferring guns to persons they knew or had reason to believe were residents of another state; ${ }^{106}$ and dealers were prohibited from shipping to private citizens in other states and from selling to those who the dealer knew or had reason to believe resided out of state. ${ }^{107}$ In the regulations promulgated under the Act, all dealers had to sign a form indicating a customer had produced identification showing he was not a resident of another state. This form, which also identified the firearms sold and gave the purchaser's name, address and description, was retained by the dealer and made available for inspection by Alcohol, Tobacco and Firearms agents. ${ }^{108}$ Thus, while the Act required the same showing of knowledge or notice to convict the dealer as the Federal Firearms Act of 1938, the duty of the dealer to obtain identification made a sale to an out-of-state resident depend on either false identification by the customer or willful law violation by the dealer. Private citizens, who could sell a gun or two from time to time, were not under a duty to verify the name and address of a transferee or to keep a record of the transaction.

The regulation of interstate traffic (in the Act and its regulations) was stronger than under the Federal Firearms Act, but there were, of course, opportunities for evasion. The sale of guns by nondealers was, from the beginning, outside of any record-keeping requirement of the Act. For a private party, the knowing transfer or interstate transportation of firearms was illegal but rarely dangerous. ${ }^{109}$ Moreover, enforcing the ban on sales to residents of another state required federal agents to inspect the forms kept by the dealers.

The credibility of the enforcement system was tied from the outset to the amount of manpower the government invested in inspecting dealer records. However, from the dealer's standpoint there was much greater risk in maintaining a high volume of illegal sales than was true before the Act, inasmuch as thorough periodic inspection could turn up patterns of illegal sales. For nondealers who used false identification to obtain guns and transport them to other states the threat posed by the record system was far more modest; the use of a false name in a federal form meant that inspection of the form and an attempt by enforcement personnel to verify the identity of the purchaser could show that the law was broken but would give no clue as to who broke the law or where the gun or offender could be located. A nondealer

108 Gun Control Act of 1968, 18 U.S.C. \& 922 (e) (1970).

107 Gun Control Act of 1968, 18 U.S.C. $\$ 922$ (b) (1970).

108 Treas. Reg. \& 178.124 (1968).

109 Gun Control Act of 1968, 18 U.S.C. \& 922 (a) (5) (1970). 
could spread his purchases out among a number of legitimate dealers, thereby obtaining a fair number of guns with relative safety for long periods of time. In order to apprehend violators of this type, enforcement agents would have to intervene at the other end of an interstate transaction, making, through undercover work, sales of firearms by nonlicensees hazardous.

Some of the problems associated with enforcing the ban on sales to nonstate residents can be tied to the decentralized nature of the firearms transaction records under the Act. The decision to keep records decentralized was made by the Treasury and endorsed by Congress ${ }^{110}$ in part to keep the regulatory aspects of the federal law distinct from any system that could be called "gun registration." The decentralized records were a tightened-up version of the record-keeping required by the Federal Firearms Act of 1938, whereas "registration" was the second dirtiest word in the vocabulary of any opponent of federal firearms regulation (confiscation was the ultimate expletive but the two were often equated). ${ }^{111}$ In part, the bad reputation of "registration" may stem from the use of a registration requirement in the National Firearms Act-where the real legislative intent was to reduce drastically ownership of covered weapons. ${ }^{112}$ But whatever its origins this fear of central records is reflected in both the Gun Control Act and the regulations issued under its mandate.

\section{B. Ownership Prohibitions}

The second major aim of the Gun Control Act was to extend the list of classes prohibited by federal law from gun ownership and to strengthen the regulatory mechanism designed to enforce the federal prohibition. The Federal Firearms Act had prohibited the receipt of a firearm by felons, fugitives from justice, persons then under felony indictment in state or federal courts, and persons not qualified to own the firearm in question in their state or locality. ${ }^{113}$ The list of prohibited classes in the 1968 Act was larger in the number of persons prohibited and included a wide variety of disqualified classes. The new federal prohibition barred licensees from the knowing transfer of a gun or ammunition to:

(1) Minors (under eighteen for shotguns and rifles; under twenty-one for handguns).

110 Gun Control Act of 1968, 18 U.S.C. \& $923(\mathrm{~g})$ (1970); Treas. Reg. \$ 178.121 (1968). See also Federal Firearms Act [II], supra note 44, at 94-95; note infra.

111 Robert J. Kukla, Gun Control: A Written Record of Efforts to Eliminate the Private Possession of Firearms in America (1973).

112 See text accompanying note 33 supra.

113 Federal Firearms Act, ch. 850, \& 2(f), 52 Stat. 1251 (1938). 
(2) Persons convicted of a state or federal felony, as well as the fugitives and defendants under indictment covered by the F.F.A.

(3) Adjudicated mental defectives and any person who had been committed to a mental institution.

(4) Persons who are unlawful users of or "addicted to marijuana or any depressant or stimulant drug . . . or narcotic drug." 114

In addition to these prohibitions, it was unlawful for any person in the prohibited classes to receive any firearm or ammunition that had been shipped in interstate commerce. ${ }^{115}$ And Title VII of the Gun Control Act also prohibited felons, persons who have received dishonorable discharges from the Armed Forces, former United States citizens and aliens illegally in the United States from receiving, possessing or transporting guns "in commerce or affecting commerce."116

The purpose of these prohibitions was to deny access to guns and ammunition to these defined special risk groups or, failing that, to punish possession of a firearm as a federal offense, whether or not the possession was in violation of local law. In order to understand how these prohibitions might work in practice, it is necessary to refer to the general scheme of regulation established by the Act. Since it is unlawful for a dealer, manufacturer or importer to transfer a firearm or ammunition to a nonlicensee only if the transferor knows or has reason to believe his customer is ineligible to receive the commodity, the dealer can be apprehended for violating the law only when the regulations governing his transfer require him to verify his customer's eligibility. ${ }^{117}$

The federal ban on sales to minors was supported by a regulation requiring the dealer to verify his customer's age by inspecting a document that shows the age on its face. ${ }^{118}$ Unless the customer uses false identification, minors cannot buy guns from dealers who are in compliance with the Gun Control Act. This is not to say that firearms were unavailable to minors; guns could be purchased from nondealers, who were not required to verify age prior to transfer, and minors could always persuade adults to buy guns for them from federally licensed dealers. But the direct sale from dealer to minor was regulated by the verification requirement, in the same way that the ban against sale to nonresidents was supported by the requirement that a transferee's address be verified. ${ }^{119}$

The ban against sales to felons, drug users and other prohibited classes was not supported by a similar verification procedure. A dealer needed only

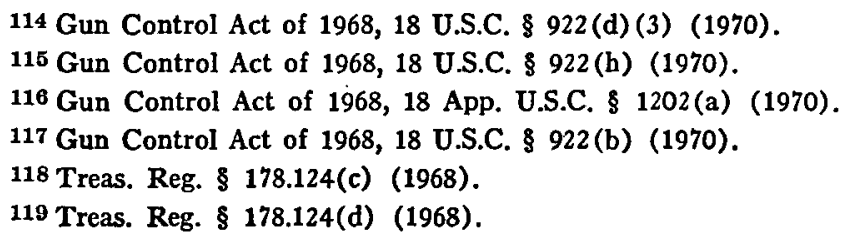


to take his customer's word for the fact that he was not ineligible to receive a gun or ammunition; the customer who made false statements of this kind would be criminally liable if the transaction were later investigated, but the dealer was not in jeopardy. Thus, while obtaining a firearm is illegal for these persons, the regulation of dealers did not shut off the access to guns for those who were willing to misrepresent their status.

The Act's limited dealer verification system approaches the natural boundaries of personal identification in the United States today. Age and address are two elements of personality that appear on drivers' licenses, selective service cards, and other significant documents that almost all adults carry. We do not live in a society that issues cards to all citizens showing whether they have been committed to mental institutions or convicted of felonies. Verification of such status would thus have to depend either on taking the customer's word for it (and auditing transfer records later to detect misrepresentation), or on creating separate screening procedures. One method of dealer verification would be a system where the dealer forwards a notice of a proposed transaction to a federal agency, which then checks a central record file to determine a customer's eligibility. Such a system, if designed to verify eligibility before purchase, would require a waiting period before any covered firearm could be purchased. It would also require centrally stored federal records of all the data relevant to determining eligibility, or elaborate referrals to other state or federal record files. ${ }^{120}$ An alternative system would be for persons who desire to purchase guns to establish their eligibility in advance by applying for a license and use the license as the means by which the dealer verifies that he is making a lawful firearm or ammunition sale. ${ }^{121}$

The Gun Control Act of 1968 stopped short of mandating either licensing or the cumbersome nationwide verification of individual transactions. With respect to felons, mental defectives, and drug users, the dealer's position under the 1968 Act is similar to his status under the Federal Firearms Act of 1938. The illegal customer may, however, be at greater risk. If a felon uses his own name and lies about his eligibility on the Form 4473 he is required by regulation to fill out, an audit of the dealer and check of the customer's criminal record will show he had violated at least two federal criminal laws, ${ }^{122}$ and he can be traced from the purchase record. ${ }^{123}$ If the customer uses false identification, gets someone else to buy from a dealer,

120 For information on the number of agencies that would have to be checked, at highly optimistic cost estimates, see George D. Newton \& Franklin E. Zimring, supra note 2 , at $129-30$.

121 A state law, e.g., is the Illinois statute Ill. Rev. Stat., ch. $38, \S \S 83-3,83-4$ (1970).

122 Gun Control Act of 1968, 18 U.S.C. $\$ 922($ h) (1970); Gun Control Act of 1968, 18 U.S.C. \& 922 (a)(6) (1970).

123 Gun Control Act of 1968, 18 U.S.C. \& 922(b)(5) (1970). 
or buys from a nonlicensee, the federal record system will not constitute a direct threat to him. However, if state or federal agents find him with a gun, a check of existing records will show whether the firearm was sold after the effective date of the Act and was thus received by him in violation of federal law. ${ }^{124}$

In sum, the scheme of regulation adopted in 1968 was of limited use in making firearms more difficult for ineligible classes to obtain, but the federal prohibitions and record-keeping requirements made it possible to convict persons ineligible to have guns if they were later apprehended with a firearm.

\section{Limitation of Imports}

Two provisions of the Gun Control Act of 1968 establish a federal strategy for limiting imported guns. Section 922(1) declares it unlawful "for any person knowingly to import or bring into the United States any firearm or ammunition . . ." or "knowingly . . . to receive" any imported firearm or ammunition "except as provided in section 925(d)."125 Section 925(d) allows the Secretary of the Treasury to permit importation if "the person importing ... the firearm or ammunition establishes to the satisfaction of the Secretary" that the firearm

(1) is being imported for scientific, research or training purposes; or

(2) is unserviceable and is being imported as a curio or museum piece; or

(3) is not a weapon covered by the revised National Firearms Act "and is generally recognized as particularly suitable for or readily adaptable to sporting purposes, excluding surplus military firearms"; or

(4) is being reimported by the person who took it out of the United States. ${ }^{120}$

Apparently, the Secretary of the Treasury was not compelled by the Act to permit the importation of any firearm or ammunition (he "may authorize" imports, rather than being told he "shall authorize" them), but he is forbidden to authorize imports except in the four circumstances outlined above. Of the exceptions listed by the section, only subsection (3) is of importance to the importation of firearms for the civilian market. Subsection (3) expressly bans the importation of surplus military firearms and allows the authorization of other firearms and ammunition only if they are "generally recognized as particularly suitable for or readily adaptable to sporting purposes." $" 127$

While the general intent of Congress in limiting firearm imports is reason-

124 Gun Control Act of 1968, \& 105(a), 82 Stat. 1226.

125 Gun Control Act of 1968, 18 U.S.C. $\$ 922$ (1) (1970).

128 Gun Control Act of 1968, 18 U.S.C. $\$$ 925(d) (1970).

127 Gun Control Act of 1968, 18 U.S.C. 8925 (d)(3) (1970). 
ably clear, the intended scope of the exception in section 925(d) is not readily discernible from its language or legislative history. ${ }^{128}$ The term "sporting purposes" is not defined in the statute, making it difficult to give a meaning to the phrase "particularly suitable to sporting purposes." Does this mean that a firearm must be a fungible sporting weapon, as useful as but no more useful than a domestically produced firearm, or that a firearm must be in some way uniquely suitable to a particular sporting purpose, so that exclusion of the gun would deny United States residents access to a form of shooting sport? If the latter is the correct interpretation, why must a gun that needs no adaptation be "particularly suitable," while a gun that needs adaptation must only be "readily adaptable" to a sporting purpose?

There are reasons to suppose that Congress wanted to give this exception a narrow meaning. The other exceptions described in section $925(\mathrm{~d})$ are quite specific and apply to particular firearms rather than classes of firearms, and the language introducing the section appears to give the Secretary discretion to ban the import of even those weapons that could qualify under 925 (d). ${ }^{129}$

The regulations issued to implement the ban on importation delegated responsibility for approving import permits to the Commissioner of Internal Revenue and provided that he could decide the "sporting purposes" issue "with the assistance of an advisory board to be appointed by the Commissioner."130 The regulations did not attempt to define what was meant by "sporting purposes." They did, however, provide for the compilation of an "import list" of firearms, thereby permitting the approval of guns for import in large numbers by different firms, once the specific model had been approved. ${ }^{131}$

It is difficult to characterize with precision the theory that animated the provisions of section $925(\mathrm{~d})$ and its supporting regulations. As "protectionist" legislation, the ban on military surplus makes sense, but the further restriction on firearms not suitable for sporting purposes is puzzling. Certainly a simple ban on military surplus would have produced fewer objections to the effect that the United States was discriminating against its trading partners by prohibiting the importation of weapons it allowed to be domestically produced. ${ }^{132}$ Further, the "sporting purposes" test would seem to have

128 Gun Control Act of 1968, 18 U.S.C. $\$ 925$ (d) (1970). See Federal Firearms Act [I], hearings on S. 1592 before the Subcomm. to Investigate Juvenile Delinquency of the S. Comm. on the Judiciary, 89th Cong., 1st Sess., at 68-69 (1965).

120 "The Secretary may authorize a firearm or ammunition to be imported . . . if the person importing .... the firearm establishes to the satisfaction of the Secretary. . . ." Gun Control Act of 1968, 18 U.S.C. \& 925(d) (1970).

130 Treas. Reg. \& 178.112(c) (1968).

131 Treas. Reg. $\$ 178.112$ (c) (1968).

132 "Saturday Night Special" Handguns, S. 2507, hearings before the Subcomm. to 
allowed the importation of firearms, particularly shotguns, that had been troublesome competition for American manufacturers, ${ }^{133}$ while excluding firearms, particularly low-priced handguns, that had not posed an important competitive threat to the established United States firearms industry. ${ }^{134}$ Finally, if the scheme of regulation was protectionist, one would have expected a more protectionist interpretation of the broad powers delegated by Congress than turned out to be the case. ${ }^{135}$

At least in part, Congress seems to have been responding to a perceived threat to public safety that resulted from the importation of low-priced "Saturday Night Specials" from abroad. Testimony before Congress suggests three themes associated with these guns: (1) they were cheap and plentiful; (2) they were low-quality and unsafe; (3) they were used in violent crimes. The image projected was not just that of a gun but of a gun and a user class. And the goal implicit in the legislation apparently was to reduce access to guns for high-risk groups by restricting the supply of cheap guns, particularly cheap handguns. ${ }^{136}$

If this was the congressional design, the legislative scheme was deficient in at least three respects. First, there was no guarantee that imposing a "sporting purposes" test would automatically reduce the number of cheap imported handguns involved in crime. Second, while the law covered both frearms and ammunition, it did not explicitly cover the importation of firearms parts; while the Act defined two major parts of a firearm as "firearms" and thus subject to restriction, other parts could be imported from abroad and assembled in the United States. ${ }^{137}$. Finally, of course, there was no guarantee that the same weapons that had been imported could not be domestically produced at slightly higher price and cause the same problems. A ban on imports might have important short-run effects on civilian acquisition of firearms and some long-term impact as a result of increased prices. But if the law was addressed to the issue of civilian ownership of firearms unsuitable for sporting purposes, the artificial distinction between foreign and domestic manufacture in the Gun Control Act of 1968 left an aura of

Investigate Juvenile Delinquency of the Senate Comm. on the Judiciary, 92d Cong., 1st Sess., at 132-33 (1971).

133 George D. Newton \& Franklin E. Zimring, supra note 2, at 172-73.

134 Id.

135 See U.S. Dep't of the Treasury, Int'l Rev. Ser., Treasury, Postal Service and General Government Appropriations for Fiscal Year 1974, hearings before a Subcomm. of the House Comm. on Appropriations, 93d Cong., 1st Sess., pt. 1, at 671 (1973); see Table 6 infra. See also note 163 infra.

${ }^{136}$ Federal Firearms Act [II], supra note 44, at 44.

137 Gun Control Act of 1968, 18 U.S.C. \& 921(a)(3) (1970); Treas. Reg. \& 178.11 (1968). 
cognitive dissonance that was to become one of the major gun control issues of the 1970s.

\section{Measuring the Effects of the Acr}

With relatively minor amendments, ${ }^{138}$ the Gun Control Act of 1968 has been the governing federal firearms control policy for more than five years, a period sufficient to invite inquiry about its impact. This part of the article (1) presents data on the administration of the Act, (2) explores the rate of civilian acquisition and use of handguns after the "Saturday Night Special" ban, and (3) analyzes how the act affected the interstate flow of handguns into states and cities that attempt to restrict gun ownership.

\section{A. Administering the Act}

One important lesson to be derived from studying the Federal Firearms Act of 1938 is the critical role played by those who administer and enforce firearms legislation. Enforcement of the 1968 Act-as was the case with the two prior efforts at firearms control-was vested in the Department of the Treasury and, within the Treasury, in the Bureau of Internal Revenue. In 1942 the Commissioner of Internal Revenue assigned firearms enforcement responsibility to a division within his bureau that supervised the tax collection, regulation and criminal enforcement functions of federal law in relation to alcohol and tobacco. The Alcohol, Tobacco, and Firearms Division (A.T.F.) had a central office in Washington, with a director who was subordinate to the Commissioner of Internal Revenue, and seven regional administrators, each responsible to the Regional Director of the Internal Revenue Service. In 1972 the Treasury reorganized A.T.F. as a separate bureau, no longer under the Commissioner of Internal Revenue. ${ }^{139}$

The old A.T.F. division had been responsible for both criminal enforcement and regulatory enforcement of federal firearms laws since 1951, but firearms regulation had a relatively low priority and a small share of the division's manpower was detailed to firearms enforcement. ${ }^{140}$ The Gun Control Act of

138 Title II, \& 13, of the Omnibus Crime Control Act of 1970, Pub. L. No. 91-644, 84 Stat. $1880,1889-90$ amended $\S 924$ (c) of Title 18 to provide an additional sentence of not less than one year nor more than ten years for federal crimes in which a firearm is used or for federal crimes in which a firearm is carried unlawfully. In the case of a second or subsequent conviction under this subsection, such person shall be sentenced to not less than two (used to be five) nor more than twenty-five years. The court shall not suspend the sentence in the case of a second or subsequent conviction or give a probationary sentence. Section 13 prohibited allowing terms of imprisonment imposed under this subsection from running concurrently with any term of imprisonment imposed for the commission of such felony.

139 T.D.O. No. 221, 1972-1 Cum. Bull. 777 (1972).

140 See note 52 supra. 
1968 and support within the Administration for firearms regulations shifted the manpower priorities of A.T.F. rather quickly. During fiscal 1968, the last full fiscal year prior to the Act, 311 man-years were listed as devoted to firearms enforcement. ${ }^{141}$ In fiscal 1970, the first full year after the Act went into effect, enforcement effort was reported as 814 man-years. ${ }^{142}$ Thus, an early impact of the Act and of the interest in gun regulation that motivated its passage was to put the federal government in the firearms regulation business at a level of manpower that was much greater than in prior years.

The two major areas in which A. T. F. invests manpower are "regulatory enforcement" and "criminal enforcement" of the federal firearms laws. ${ }^{143}$ Regulatory enforcement is the supervision of federal licensees-importers, manufacturers, and dealers. At the dealer level, the key tasks of regulatory enforcement are the investigation of initial applications for dealer licenses and compliance investigations to determine whether dealers are conducting business in accord with federal law. The investigation of an initial application involves an inspection of the proposed premises, a background investigation of the applicant, and an interview about the nature of the business that is contemplated. A compliance investigation involves re-inspection of business premises, inspection of the dealer's records, and an audit of a few firearms transaction report forms to determine whether the information is recorded properly and whether a check of the customer's listed address and criminal record shows any violation of federal law. Apparent violations of law may, in the agent's discretion, be referred to the criminal investigation staff in the same A.T.F. office for further investigation.

A larger share of A.T.F. manpower is devoted to criminal enforcement activities by special agents with arrest powers. ${ }^{144}$ While regulatory enforcement is focused on dealers with federal licenses, criminal enforcement activities are devoted to the broad spectrum of illegal firearms possession and traffic. A relatively small part of criminal enforcement work involves licensed dealers-estimated at less than 30 per cent, with no precise breakdown available. ${ }^{145}$ Other types of investigation include undercover work to find black-market sellers, investigation of persons who are suspected of illegal possession as a result of information passed on by regulatory enforcement

141 Estimates provided by Regional Offices, U.S. Bureau of Alcohol, Tobacco and Firearms.

142 Ibid.

143 Appropriations for Fiscal Year 1974, supra note 136, at $682-83,686$.

144 Id. at 705.

145 At present, the management information system used by the Bureau of Alcohol, Tobacco, and Firearms does not generate data on percentage of criminal enforcement devoted to dealers. 
staff, local police or informants, and investigation of persons who are special targets of local or federal authorities.

Available statistics, though incomplete, give some indication of A.T.F. performance after the Gun Control Act of 1968 came into existence. As to regulation, the first effect of the Act was to generate the need to make a large number of investigations of applications for dealer licenses. The Treasury had hoped that raising the annual fee for federal dealer licenses to ten dollars and instituting standards for granting licenses would reduce the number of persons applying for licenses, thereby making meaningful regulation of dealer activities feasible. But the higher fee was offset by the fact that, after the Act, the only way to receive firearms in interstate commerce was to obtain a federal license. The number of dealer and collector licenses in effect never dropped below $60,000^{146}$ and is presently estimated at 160,000 , compared to about 100,000 during the early 1960 s. ${ }^{147}$

The need to investigate license applications reduced the manpower available for compliance investigations and, to some extent, for criminal enforcement initiatives. The press of putting the law into effect, and the decentralized tradition of A.T.F. activities, also put limits on the ability of A.T.F. to invest resources in strategic planning to define priority problems and measure the effectiveness of regulatory and criminal enforcement efforts. And the focus on initial applications and other "start-up costs" associated with the Act were followed, in 1970, by a federal law requiring A.T.F. to regulate explosives. ${ }^{148}$

Yet criminal enforcement activities did pick up substantially, as shown by the summary data on federal firearms cases for the fiscal years 1968-1973 in Table 1.

TABLE 1

Federal Firearms law Cases Recommended for Prosecution, Indictument and Convictions by Fiscal YeaR-1968-73

\begin{tabular}{lrrrrrr}
\hline & 1968 & 1969 & 1970 & 1971 & 1972 & 1973 \\
\hline Cases Recommended for & & & & & & \\
$\quad$ Prosecution by A.T.F. & 375 & 1341 & 3212 & 3407 & 4031 & 3283 \\
Indictments & 175 & 331 & 1309 & 1888 & 2444 & 2257 \\
Convictions & 89 & 178 & 577 & 1148 & 1451 & 1719 \\
\hline
\end{tabular}

Source: U.S. Treasury Dep't, Bureau of Alcohol, Tobacco and Firearms, Statistics Division.

148 Personal communication from Carl Perian (Phoenix, Arizona, April 3, 1974).

147 Personal communication from Peter Velde (Phoenix, Arizona, April 3, 1974).

148 Organized Crime Control Act of 1970, Title XI, \$\$ 841-849, 18 U.S.C. $\$ \$ 841-849$ (1970). Section 847 vests administration of the chapter in the Secretary of the Treasury. Delegation Order No. 31 (Rev. 2), 1970-2 Cum. Bull. 487, delegates regulation powers to the Bureau of Alcohol, Tobacco, and Firearms. 
As Table 1 shows, cases recommended for prosecution rose from 375 during fiscal 1968 (the last full year before the passage of the Act) to over 3200 during 1970 (the first full fiscal year after). Convictions, which occur some time after enforcement efforts end, increased from 89 during fiscal 1968 to 1148 during fiscal 1971 .

Some data are available on the pattern of criminal enforcement before and after the Gun Control Act. The statistics division of A.T.F. records information on charges recommended and results by the title in the Gun Control Act under which charges were recommended. This gives some indication of the type of activity that led to the recommendation of charges, because Title II of the Gun Control Act deals with machine guns, sawed-off shotguns, and destructive devices subject to special taxes and registration, while Title VII of the Act deals exclusively with the receipt or possession of firearms by prohibited classes. This type of reporting does not give an accurate picture of the extent of enforcement activity relating to interstate flow of weapons, inasmuch as Title I of the Act, which prohibits such transfers, also prohibits dealing in firearms without a federal license and a variety of other activities. ${ }^{149}$ Table 2 shows the pattern of criminal enforcement by fiscal year for A.T.F. referrals for prosecution.

The figures in Table 2 suggest a continued heavy emphasis by A.T.F. on

TABLE 2

Percentage Distribution of Cases Referred for Prosecution by Type of Charge by Fiscad Year 1968-73

\begin{tabular}{lcccccc}
\hline & 1968 & 1969 & 1970 & 1971 & 1972 & 1973 \\
\hline $\begin{array}{l}\text { National Firearms Act } \\
\text { Charges (N.F.A. Title }\end{array}$ & & & & & & \\
$\begin{array}{l}\text { II of the Gun Con- } \\
\text { trol Act) }\end{array}$ & 55 & 49 & 36 & 42 & 39 & 39 \\
$\begin{array}{l}\text { Prohibited Person Re- } \\
\text { ceiving or Possessing }\end{array}$ & & & & & & \\
a Firearm (Federal \\
$\begin{array}{l}\text { Firearm Act and Title } \\
\text { VII of the Gun Con- } \\
\text { trol Act) }\end{array}$ & 39 & 39 & 35 & 34 & 27 & 29 \\
$\begin{array}{l}\text { Title I of Gun Control } \\
\text { Act }\end{array}$ & & & & & & \\
Combined Charges b & 5 & 12 & 7 & 5 & 30 & 28 \\
$\quad$ Total & $100 \%$ & $100 \%$ & $100 \%$ & $100 \%$ & $100 \%$ & $100 \%$ \\
$\quad$ & $(375)$ & $(1341)$ & $(3212)$ & $(3407)$ & $(4031)$ & $(3283)$ \\
\hline
\end{tabular}

- Includes any case with a Title VII recommendation.

- Excludes Title VII cases.

Source: U.S. Treasury Dep't, Bureau of Alcohol, Tobacco \& Firearms, Statistics Division.

149 Gun Control Act of 1968, 18 U.S.C. \& 922 (1970). 
the special class of weapons regulated under the provisions of the amended National Firearms Act (heavy in relation to the number of such weapons in circulation), and indicate that at least as many prosecutions are recommended because a prohibited person has been found in possession of or has received a firearm as are the result of detecting violations of the ban on sales to nonstate residents and illegal transportation and sales.

What these figures do not show is the proportion of A.T.F. enforcement effort that is devoted to the "state aid" aims of the Act, or the impact of A.T.F. criminal enforcement on the flow of guns. No figures are kept on the proportion of criminal enforcement effort or referrals that relate to dealers or major traffickers, or on the number of firearms involved in the transactions investigated.

A humbling comparison can be made between the enforcement resources available to A.T.F. and the size of the problem it is charged with policing. About 5,000,000 new firearms were sold on the civilian market in 1973, and approximately the same number of used firearms changed hands. Audits of frearms transaction records show apparent irregularity in a large enough proportion of these to generate several hundred thousand criminal investigations a year if all transaction forms were audited, and that is not the major source of the illegal interstate movement of firearms. ${ }^{150}$ There may be as many as half a million violations of the Gun Control Act of 1968 each year, with most of them at least one step beyond the record system imposed on dealers and first-purchasers. Criminal investigation of transfers outside the record system requires a considerable amount of manpower, invested in proactive police work aimed at detecting victimless crime. Under these conditions the primary determinant of the degree of enforcement will be the resources committed to enforcement. And as the dip in case referrals for 1973 might suggest, manpower allocated to A.T.F. firearms enforcement has remained relatively stable in the past two years. ${ }^{161}$

If limited manpower is one major constraint on achieving the "state aid" purposes of the Act, lack of information on the pattern of illicit traffic in firearms has also proved to be a major obstacle. Prior to 1972 there were no major investigations by the Bureau of where the firearms that were frustrating state and local gun control efforts came from. A series of studies of interstate handgun traffic was begun in 1972 and will be referred to in the discussion of the impact of the law on the interstate gun problem. Information

\footnotetext{
150 No precise estimate is possible because the audited forms were not a random sample. The random sample figure would suggest that $2 \%$ of all 2.4 million new handgun transactions suggest some apparent irregularity.

151 The Bureau of Alcohol, Tobacco, and Firearms reports that man-days invested in firearms enforcement increased from 80,000 in fiscal year 1968 to a reported 252,126 in fiscal year 1972. The parallel figure for 1973 was 258,983 .
} 
on the number of firearms produced in the United States was not compiled by A.T.F. until 1972, and data on firearms sales in the various states and regions are still not available.

A further limit on the ultimate effectiveness of A.T.F.'s enforcement effort has been the types of firearms traffic left uncontrolled under the Act and the regulations established to govern its enforcement. Detailed records of firearms transfer by dealers are now required, but these records are kept by the dealer and are only accessible to the Bureau during compliance investigations or when agents are alerted to a particular gun or dealer as a result of other information. ${ }^{152}$ Whatever value firearms transaction records would have -in providing a picture of retail firearms traffic and in putting the Bureau on notice of special high-risk high-volume sales patterns-was sacrificed to decentralization. And nondealer gun transfers-probably 30 per cent of total gun traffic and a far higher proportion of illegal sales ${ }^{153}$ - are not subject to any federal record-keeping requirement.

A final limit on the effectiveness of Bureau efforts is the sheer volume of firearms in civilian hands. Regulation of firearms traffic as a whole differs from efforts to control submachine guns and hand grenades, not in degree but in kind. The number of National Firearms Act weapons in civilian hands in the United States is small, and federal law was explicitly designed to keep ownership low. ${ }^{154}$ Civilian firearms ownership exceeds $100,000,000,{ }^{155}$ and any federal efforts at regulation must involve only a small percentage of gun transactions or an enormous regulatory effort. For example, the director of A.T.F. reported an estimated 25,000 dealer-compliance investigations during fiscal $1973 ;^{156}$ a sample of 100 such investigations conducted by the Chicago regional office showed an average of five firearms transaction forms were traced for criminal record and address verification in the course of each investigation. If that approximates the national average, about 125,000 transactions a year are verified in the course of the Bureau's regulatory enforcement. That is an impressive workload, but still constitutes less than two per cent of the annual retail commerce in guns.

Notwithstanding its limits, efforts to effectuate the Gun Control Act reflect a much more serious commitment of resources and support than resulted from the Federal Firearms Act of 1938, and the 1968 Act is worthy of more attention than it has previously received.

\footnotetext{
152 Treas. Reg. $\S 178.121$ (1968). Treas. Reg. $\$ 178.23$ (1968) gives internal revenue officers rights of entry and examination.

153 George D. Newton \& Franklin E. Zimring, supra note 2, at 13 (Figure 3-1).

154 See text accompanying note 33 supra.

155 George D. Newton \& Franklin E. Zimring, supra note 2, at 5. See also Table 5 infra. 156 Appropriations for Fiscal Year 1974, supra note 135, at 682.
} 


\section{B. The Saga of the "Saturday Night Special"}

As previously discussed, the Gun Control Act prohibited the importation of all military surplus firearms and any other firearms unless the Secretary of the Treasury found them to be generally recognized as "particularly suitable for or readily adapted to sporting purposes."157 This section discusses the interpretation of that provision, the impact of the law as interpreted on handgun importation, sales, and misuse, and the consequences of the "Saturday Night Special" ban on the federal firearms control debates of the 1970s.

I have previously suggested that the operative provisions of section 925 (d) could have been interpreted as giving the Secretary of the Treasury power to end all firearms importation into the United States. ${ }^{158}$ That reading, heavily dependent on the fact that the Secretary was not required to issue any import authorization, was never given any serious consideration in discussions of the Act ${ }^{159}$ or in the regulations issued under it. ${ }^{160}$ The argument against such a reading is strong: why would Congress so obliquely delegate to the Treasury the power to determine at will whether firearms could be imported, and why would Congress establish criteria for importation if it was delegating the power to ignore them? In any event, the Internal Revenue Service read section 925 (d)(3) as requiring the Service to permit the importation of all firearms that met the standards established by subsection (3), and the "sporting purposes" test became the border between permissible and impermissible importation. ${ }^{161}$

Construing this provision created no major difficulty in the regulation of shotguns and rifles, for different reasons. The bulk of the foreign-made shotguns imported into the United States are of high quality and reputation. While these weapons were a major competitive challenge to American manufacturers, it would be hard to imagine a "sporting purposes" test that would exclude a large number of them. Rifle imports presented no major interpretation problem under 925 (d)(3) because surplus military weapons, constituting the bulk of low-priced rifles during the late 1950s and 1960s, were excluded from the United States whether or not they were particularly suitable for sporting purposes. ${ }^{162}$ Rifle imports dropped somewhat after the Act

157 Gun Control Act of 1968, 18 U.S.C. \& 925(d)(3) (1970).

158 See p. 154, supra.

${ }^{159}$ See Federal Firearms Act [II], supra note 128, at 69.

160 U.S. Dep't of the Treasury, Int'l Rev. Ser., Factoring Criteria for Weapons, Form 4590 (11-69) reprinted in Appropriations for Fiscal Year 1974, supra note 135, pt. 1, at 671 (1973).

161 Ibid.

162 Gun Control Act of 1968, 18 U.S.C. § 925(d)(3) (1970). 
went into effect, while shotgun imports more than doubled between 1968 and $1973 .{ }^{163}$

The hard questions concerning the "sporting purposes" test related to handguns, because the handgun, whether domestic or imported, is not primarily a sporting weapon. In contrast to rifles and shotguns, handguns are owned more frequently in cities than in rural areas, are rarely used to hunt with, and are viewed by consumers as weapons of self-defense. ${ }^{164}$ Handguns are carried by some hunters as a "finishing weapon" for killing wounded animals, and are widely used for informal target practice ("plinking"). But it is unclear whether these uses would or should have been considered sporting purposes, nor is it clear what kind of handguns should be considered generally recognized as particularly suited to shooting at tin cans. The essential problem, then, was that the "sporting purposes" test was something of a non sequitur when applied to handguns, because the great majority of them were not, in any event, intended for sporting purposes.

Under these circumstances, interpreting the "sporting purposes" standard was bound to cause problems. One approach would have been to prohibit the importation of any pistols or revolvers. This was apparently within the power of the Treasury but would have produced a storm of partially justified criticism, since Congress had not explicitly singled out handguns for exclusion. A second approach would have been for the Internal Revenue Service to issue regulations requiring importers to establish to its satisfaction that a particular shipment of handguns would be used for shooting-sports activities. Though this interpretation would doubtless have produced controversy, it seems most clearly in line with a congressional "sporting purposes" test: why should such a test govern importation decisions if congressional intent were not to allow the importation of only sporting weapons? Such a regulation could be justified for handguns, as opposed to rifles and shotguns, because long guns were, as a class, generally regarded as sporting weapons, while handguns were not. ${ }^{105}$ The effect of this kind of regulation, if the burden of proof rested on the importer in each case, would have been to reduce handgun imports drastically and confine the import market to target pistols for which domestic substitutes were either unavailable or so much more expensive that seeking permission to import the weapons would be worth its considerable trouble. Whether this would have resulted in substantially re-

1631968 rifle imports and shotgun imports are reported in George D. Newton \& Franklin E. Zimring, supra note 2, at 172-173. 1970 rifle imports totaled 218,979. 1970 shotgun imports totaled 422,100 . (1970 figures supplied by Bureau of Alcohol, Tobacco, and Firearms.)

164 George D. Newton \& Franklin E. Zimring, supra note 2, at 11, 21, 61.

165 Id. at 61 . 
ducing total handgun sales or handgun violence is a question to be considered later.

The approach taken by the Internal Revenue Service was to establish a system for grading pistols and revolvers, together with a list of approved guns that could be imported with relatively little red tape. Guns without specified safety accessories, or understated minimum size, were excluded. The import criteria for grading other weapons included gun and barrel length, type of frame construction, and weight. ${ }^{166}$ And the Service reserved the right "to preclude importation of any revolver or pistol which achieves an apparent qualifying score but does not adhere to the provisions of section 925(d)(3) of . . . Ch. 44, Title 18, U.S.C."167

The impact of these "Factoring Criteria for Weapons" was to exclude very small handguns and those without safety devices, and to create standards of frame construction and handgun weight to qualify for import. The weight requirement would differ with different weapons, because deficiencies in weight can be compensated for by the presence of target equipment, safety features, or other graded items. ${ }^{168}$

There is a ring of arbitrariness about a single "passing score" determining whether or not a handgun is a "Saturday Night Special"-a revolver with a 44-point score would not be approved, whereas one with 46 points became "particularly suited to sporting purposes." But the "Factoring Criteria for Weapons" did give a measure of certainty to the process of approving or disapproving handguns for importation. Perhaps the standards gave a bit too much certainty, in that foreign manufacturers could integrate U.S. specifications into the design of handguns.

The theories behind the various criteria chosen by the Commissioner are not explicitly set out in any public documents. Frame length and barrel length of a handgun are relevant to its concealability, and very short handguns are not likely to be used for formal target shooting. Weapon weight and frame construction may be related to durability. Safety features make it less likely that a handgun will discharge accidentally, particularly when dropped. The caliber of a handgun may be of some relevance to the likelihood of its being used for a sporting purpose (high-caliber handguns receive extra points), yet the majority of handguns used for informal "plinking" are .22 caliber, if only because .22 caliber ammunition is relatively inexpensive.

Taken together, the standards employ criteria that are to some degree relevant measures of handgun quality, whether a handgun is used for self-defense

166 U.S. Department of the Treasury, Int'l Rev. Ser. Factoring Criteria for Weapons, Form 4590 (11-69). See note 135 supra.

167 Ibid.

168 Ibid. 
or sporting purposes. But neither the criteria nor the cutoff points (45 for revolvers, 75 for pistols) have become accepted standards for defining the "Saturday Night Special." In 1973, A.T.F. attempted to determine the proportion of guns in a sample of confiscated handguns that could be classified as "Saturday Night Specials." Instead of using the "Factoring Criteria for Weapons" cutoff, the Bureau used three different standards-guns retailing for less than $\$ 50$, guns with a barrel length of three inches or less, and guns of .32 caliber or less. "[T]he problem of determining what percentage of the total guns traced fell in the category of 'Saturday Night Specials' was resolved by taking the total number of guns in each of these three categories, adding the totals, and dividing by three to arrive at what was called a 'composite' average."169

What is remarkable about the series of events that led to the "Factoring Criteria" and the list of foreign firearms approved for importation is the persistent nondefinition of the key terms in the controlling federal law. We have now traced through the three significant levels of congressional and agency declaration-the statute itself, the regulations issued to implement the statute, and the "factoring criteria for weapons." At no point in this sequence is the phrase "particularly suitable . . . for sporting purposes" or any of its constituent terms explicitly defined. Yet at the end of this process, A.T.F. had created a set of precise criteria to govern the importation of handguns!

A major share of the responsibility for this state of affairs belongs to the draftsmen of section $925(\mathrm{~d})$ and to Congress. The "sporting purposes" test was ill-suited to the task of sorting out foreign handguns, yet handgun imports were the only significant issue to be decided by that standard. While the agency charged with responsibility for administering the Act could have made a wholesale determination that almost all handguns were barred from importation, a clearer congressional mandate for such a controversial step would have been desirable.

The jurisprudence of the entire "Saturday Night Special" issue is also interesting. The attack against cheap imported handguns was powerful but pitifully underinclusive. Handguns retailing for under $\$ 50$ are a major public safety problem-but so are those retailing for over $\$ 50$. Imported handguns were an important part of the urban arms race of the late $1960 \mathrm{~s}$, but so were domestic handguns. ${ }^{170}$ To focus on "cheap imports" created the need to find the kind of fault with these guns that would not generalize too quickly. The various complaints lodged against the "Saturday Night Special" were thus somewhat peripheral to the central problems of handgun misuse-

169 U.S. Dep't of the Treasury Bureau of Alcohol, Tobacco, and Firearms, Project Identification 3 (1973).

170 George D. Newton \& Franklin E. Zimring, supra note 2, at 50; see also id. at 171-74. 
and these distortions are faithfully reflected in the standards governing handgun imports in 1974.

The effect of the import restriction on handgun importation was immediate and dramatic, as shown in Table 3, using data from the Bureau of the Census.

TABLE 3

HANDGUN IMPORTS BY YEAR, 1965-73

\begin{tabular}{lrll}
\hline \hline 1964 & 253,000 & 1969 & 349,252 \\
1965 & 346,906 & 1970 & 226,516 \\
1966 & 513,019 & 1971 & 345,557 \\
1967 & 747,013 & 1972 & 293,343 \\
1968 & $1,155,368$ & 1973 & 309,471 \\
\hline
\end{tabular}

Source: U.S. Bureau of the Census, Foreign Trade Division, FT246-U.S. Imports for Consumption 1964-73.

Handgun imports in 1969, the first year under the Gun Control Act, were less than a third of 1968's record volume of 1,155,000, and importation in later years has never exceeded one third of the 1968 total. It is also significant that the post-1968 totals are far lower than in 1967 and 1966, years when the number of handguns imported was not affected by the deadline imposed by the Gun Control Act. These figures show a linear growth in handgun imports being replaced in 1969 by a new plateau at about one third of the 1968 rate, a further dip in 1970, and a leveling off in later years at around 300,000 units.

The figures in Table 3 are from annual reports from the Bureau of the Census on specific categories of foreign trade. The data are derived from customs records and are the only estimates of imports available for the years prior to 1969. Since December of 1968, however, A.T.F. has been compiling its own figures on firearms importation, derived from forms filed by holders of import licenses. A.T.F. statistics on handgun imports tell a somewhat different story, as shown in Table 4.

The A.T.F. and Census figures are in general agreement for the years 1969-1971, showing a sustained drop in handgun imports. The A.T.F. statistics for these years are always somewhat higher than the Census figures, because the A.T.F. definition of a handgun includes certain handgun parts and marginal weapons that the Census figures exclude. For 1972, however, the A.T.F. and Census imports diverge by 150,000 guns, and the 1973 totals of 300,000 and 900,000 respectively cannot be reconciled. ${ }^{\mathbf{1 7 1}}$ If the A.T.F.

171 In an effort to reconcile the import totals, 1973 import permits issued by the Southeastern Regional Office of the Bureau of Alcohol, Tobacco and Firearms were analyzed. It was found that the two categories that are counted as handguns by A.T.F. but not by Customs-starter guns and major handgun parts-were not a significant part of the guns imported under permit. With respect to starter guns, the Census Bureau reports a total number of 88,000 imported during 1972 . See U.S. Bureau of the Census, Foreign Trade Division, FT 246-U.S. Imports for Consumption 1972 (1973). 
TABLE 4

HANDGUN IMPORTS BY YeAR, 1964-73

\begin{tabular}{ccc}
\hline & Bureau of the Census & A.T.F. \\
\hline 1964 & 253,000 & - \\
1965 & 346,906 & - \\
1966 & 513,019 & - \\
1967 & 747,013 & - \\
1968 & $1,155,368$ & $358,083^{a}$ \\
1969 & 349,252 & 279,537 \\
1970 & 226,516 & 357,170 \\
1971 & 345,557 & 439,883 \\
1972 & 293,343 & 900,680 \\
1973 & 309,471 &
\end{tabular}

- Estimate based on a thirteen-month total of 387,924 .

Source: U.S. Dep't of Treasury, Bureau of Alcohol, Tobacco and Firearms, Statistics Division.

figures are closer to the truth, the pattern of handgun imports shows a sustained drop followed by a sharp increase in 1972 and 1973, with the 1973 total approaching the 1968 peak. With no definitive basis for choosing between these sharply different estimates, each of which claims to be based on compilations from individual records of handgun transactions, we will simply have to plead in the alternative whenever handgun import statistics for these years are needed to assess the impact of the Act. One could hope, however, that the two federal agencies in charge of compiling these data might attempt to resolve such a glaring discrepancy.

Unless imported handguns are a distinctive social control problem, the appropriate way to measure the impact of the ban on imports is the number and type of handguns, both domestic and imported, coming to the civilian United States market. In order to acquire these data, it is necessary to study patterns of domestic handgun production. One would predict that a partial ban on imports would lead domestic manufacturers to produce more weapons. This prediction is supported by the statistics compiled in Table 5 .

Table 6 shows the estimated total number of handguns introduced into the civilian market during 1963 through 1973; the disagreement on imports makes it necessary to present both "low" (using Census statistics) and "high" (using A.T.F. statistics) estimates for 1969-1973.

Annual handgun production and imports in the first three years after passage of the Act were off more than 25 per cent from the 1968 peak-year total-and approximately the same as in 1967. After that the "high" and "low" total estimates tell different stories. If the "low" estimate is accurate, an expansion in domestic production in 1972 and 1973 pushed the total number of handguns to nearly the two million mark, a unit volume 400,000 below the 1968 total. If the "high" estimate is accurate, increases in both 
TABLE 5

Estrmated Domestic Production of Handguns for Civilian Use by Year, $1964-73$

\begin{tabular}{lrll}
\hline 1964 & $491,073^{\mathrm{a}}$ & 1969 & $1,367,300^{\mathrm{c}}$ \\
1965 & $666,394^{\mathrm{a}}$ & 1970 & $1,393,690^{d}$ \\
1966 & $699,798^{\mathrm{a}}$ & 1971 & $1,420,692^{\circ}$ \\
1967 & $926,404^{\mathrm{a}}$ & 1972 & $1,667,000^{\circ}$ \\
1968 & $1,259,356^{\mathrm{b}}$ & 1973 & $1,609,0008$ \\
\hline
\end{tabular}

- Estimate based on production reported by manufacturers to the National Commission on the Causes and Prevention of Violence. See George D. Newton \& Franklin E. Zimring, Firearms and Violence in American Life 172 (1963).

b Estimate projected from production for the first six months of 1968. Ibid.

- Estimate based on handgun excise tax collections of $\$ 6,183,000$ for fiscal 1969 , and $\$ 6,697,000$ for fiscal 1970, and ratios of $\$ 4.34$ excise tax collection per handzun in fiscal 1971. The mean ratio of excise tax collection to guns (\$4.71) was divided into the mean of excise tax collections for fiscal 1969 and fiscal $1970(\$ 6,440,000)$ to derive an estimated calendar-year production of $1,367,304$ handguns. Fiscal-year estimates of handgun production for 1968 and 1971 were derived from the mean of production for the two calendar years that were pertinent. Our estimate of production deviated from that of the Treasury (which simply divided total production for 1967, 1968, 1970 and 1971 by four) by a total of 112,000 handguns, or nine per cent.

d Estimate based on A.T.F. survey of domestic manufacturers.

- Estimate based on A.T.F. survey of "confidential industry sources."

I Estimate based on A.T.F. survey for first six months, quarterly reports to A.T.F. for July-December. Handgun exports deleted.

8 Estimate based on quarterly report by manufacturers to A.T.F.

production and imports pushed unit volume above two million in 1972 and above the 1968 peak in 1973.

While the peak rate of 1968 may not be an ideal candidate for a base year, the figures in Table 6 suggest that the new import restrictions did have an immediate and substantial impact on the number of handguns that came into the civilian market; as might have been expected, however, domestic production expanded after the Act, and the increase in domestic capacity was equal by 1973 to about half the $1,100,000$ handguns that were imported in 1968.

TABLE 6

Handoun Production and Imports by Year, U.S., 1964-73 (in thousands)

\begin{tabular}{ccc}
\hline & Low Estimate & High Estimate \\
\hline 1964 & 744 & - \\
1965 & 1002 & - \\
1966 & 1213 & - \\
1967 & 1673 & - \\
1968 & 2414 & 1725 \\
1969 & 1716 & 1672 \\
1970 & 1619 & 1777 \\
1971 & 1765 & 2100 \\
1972 & 1960 & 2510 \\
1973 & 1918 & \\
\hline
\end{tabular}


In part, the expanded domestic output reflected the production of domestic "Saturday Night Specials." The importation of handgun parts for United States assembly grew from a unit volume of 18,000 in 1968 to more than a million in 1972. ${ }^{172}$ The average value of a United States handgun (as indicated by the ratio of production to excise tax collections) fell by about 10 per cent between 1969 and 1972, during a period of general inflation. ${ }^{173}$ Yet the impact of the importation restrictions was substantial in the years immediately following the Act and could have been even more substantial if a tighter definition of "sporting purposes" and restrictions on the importation of handgun parts had materialized.

There are two ways of measuring the impact of restricted supplies of handguns on the rate of handgun violence. The first is to compare the rate of civilian handgun acquisition with rates of handgun violence; the second is to trend the proportion of violent activities attributable to handguns over time. The first method is the most frequently used, but fails to control for the many variables other than gun availability that may influence the rate at which crimes are committed with all weapons, including guns. The second method seeks to control for other factors influencing crime rates by focusing on relative rather than absolute measures of gun use. Both approaches show the same general pattern for the period 1966 through 1973-explosive growth in the rate of handgun usage in the period 1966-1969 followed by three years in which handgun violence continued to grow, but at a more modest rate.

Figure 1 shows trends in handgun homicide and nonfatal assault by firearms in the 57 largest United States cities. The assault figures, which are not broken down by type of firearm, should be composed of about 80 per cent handgun attacks, since 79 per cent of all firearms homicides during the period were committed with handguns in these cities.

Handgun homicides and gun assaults increase consistently throughout the period, but the rate of increase slows considerably after 1969. Assuming about a one-year lead time for guns produced or imported to reach city streets, the moderating rate of increase coincides with the reduction in new handguns entering the civilian market.

Figure 2 shows handgun homicides and firearm assaults as a percentage of all homicides and assaults for the same cities.

Figure 2 reveals substantial increases in the percentage of homicides attributed to handguns and assaults attributed to firearms; these moderated beginning in 1969, but continued to trend upward. If, as seems likely, these percentages are related to the rate at which handguns enter the civilian

172 Robert Sherrill, supra note 6, at 304 . The dollar volume of imported handgun parts in 1972 totaled $\$ 3,500,000$.

173 I.R.S., Annual Report of the Comm'er, 1969, tab. 3, at 107; id., 1972, tab. 3, at 111. See Table 5 infra for handgun production estimates. 


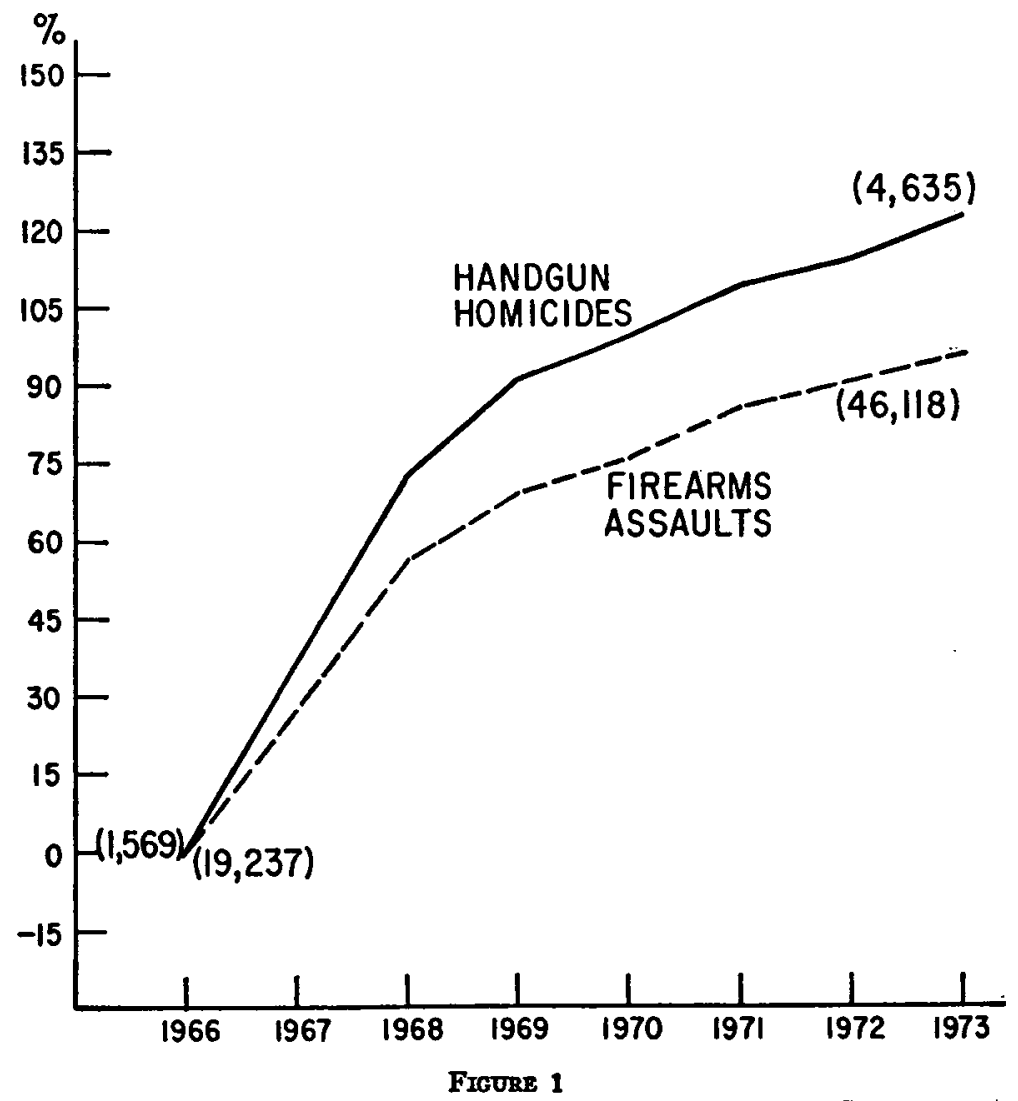

Trends in Handgun homicides and Firearas Assaults, 57 Citmes with Population 250,000 OR MORE, BY Year 1966-1973

market, both handgun attacks and the percentage of all attacks attributable to handguns should show further upward movement in 1974, particularly if the A.T.F. estimate of imports (the high estimate in Table 6) is the more accurate.

In part because of the import restrictions and their aftermath, the "Saturday Night Special" issue became the focal point for firearms-control debate in the early 1970s. Using the uneasy conceptual framework of section 925(d) (3) as a starting point, proposals to extend production controls to domestic handguns proceeded in three different directions. One set of proposals, never widely supported in Congress, used the artificiality of the distinction between "Saturday Night Specials" and other handguns as a platform for urging prohibition of handgun production and sale for the civilian market. ${ }^{174} \mathrm{~A}$ second approach

174 H.R. 3980, 92d Cong., 1st Sess. (1971). 


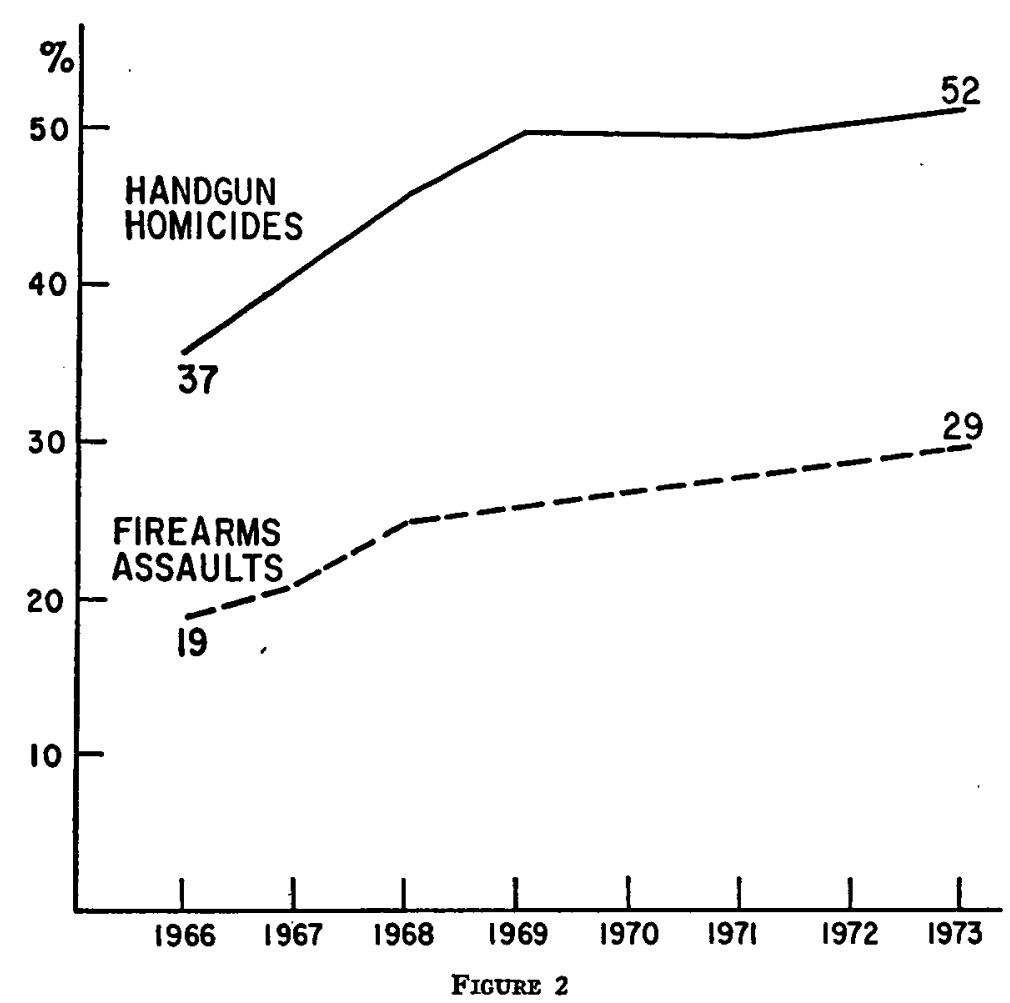

handgun Homicide as a Percentage of Total Homicide, and Firearm assault as a Percentage of Total Assault, by Year in 57 U.S. Cittes over 250,000

was Senator Bayh's proposal to extend the existing A.T.F. minimum standards of length and quality to domestically produced handguns; his bill, S. 2507, would have prevented the sale of many handguns produced by established United States firms that were smaller than the minimum standards in the bill. ${ }^{178}$ The Bayh bill passed the Senate in 1972 but never came to the floor of the House. ${ }^{178}$

A third approach, which enjoyed considerable support in the Congress and the Administration, sought to amend the "Factoring Criteria for Weapons" into a test of handgun reliability and to extend this type of regulation to both imported and domestic handguns. Federally funded tests of handguns were performed by the H. B. White Laboratories in 1972, and there was talk of an Administration proposal to amend section 925(d), but no such proposal

176 S. 2507, 92d Cong., 1st Sess. (1971).

176118 Cong. Rec. 27502 (1972).

177 Gun Control Legislation, hearings before Subcomm. No. 5 of the H. Comm. on the Judiciary, 92d Cong., 2d Sess., serial no. 33, at 239-40 (1972). 
was introduced. ${ }^{177} \mathrm{~A}$ number of proposals have been introduced in Congress and state legislatures using criteria such as melting point or reliability test survival as criteria for minimum handgun quality. 178

Most of the descendants of section 925(d) suffer from the same aroma of arbitrariness that surrounded the debate in 1968 and the standards promulgated under the 1968 act. The Bayh bill used the previously discussed "factoring criteria" developed to test foreign handguns. ${ }^{179}$ The bill seems to have been inspired by reports of domestically produced "Saturday Night Specials," and the criteria and cutoff points were borrowed from the A.T.F. import standards to avoid the tricky problem of establishing and defending independent standards. The various proposals to make handguns "reliable" oddly did not include shotguns and rifles, as one would assume a genuine consumer-safety proposal for firearms should. The special problems associated with handgun possession and use have achieved a great deal of public attention, but the second generation "Saturday Night Special" bills do not address what appears to be the central problem: the misuse of handguns, rather than of any recognizable subclass of handguns.

One lesson of the 1968 import restrictions is that a production standard need not be conceptually acceptable to have impact on the United States handgun market. Any standards that disrupt handgun production can have short-run effects, and any standards that raise prices significantly or restrict production capacity can have some long-range impact on handgun sales and use. The problem with this type of partial solution is not merely that it has "loopholes" through which compensating increases in production can flow: it also lacks coherent principle. The mechanism used by section 925 (d)(3) -shutting off the flow of a particular type of weapon-might work with a relatively high degree of effectiveness if only we could determine what it is that we really want to prohibit.

The fluctuation in handgun violence over the past eight years also suggests, for good or ill, that the rate at which new handguns enter the market has a special impact on handgun violence. The 2.4 million new handguns entering the market in 1968 were a less than 15 per cent addition to the total domestic supply, yet were associated with a far larger increase in handgun homicides. ${ }^{180}$ In part this "leverage" may simply reflect the fact that the same forces that influence crime rates increase the demand for handguns, in which case a legislated reduction in handgun production and imports will not necessarily result in a disproportionate reduction in handgun violence.

178 See, e.g., the Illinois proposal, HB-1058, 78th General Assembly (1973).

179 S. 2507, 92d Cong., 1st Sess. (1971).

180 See Table 6 supra; Figure 1 supra; George D. Newton \& Franklin E. Zimring, supra note 2 , at 172-73. 


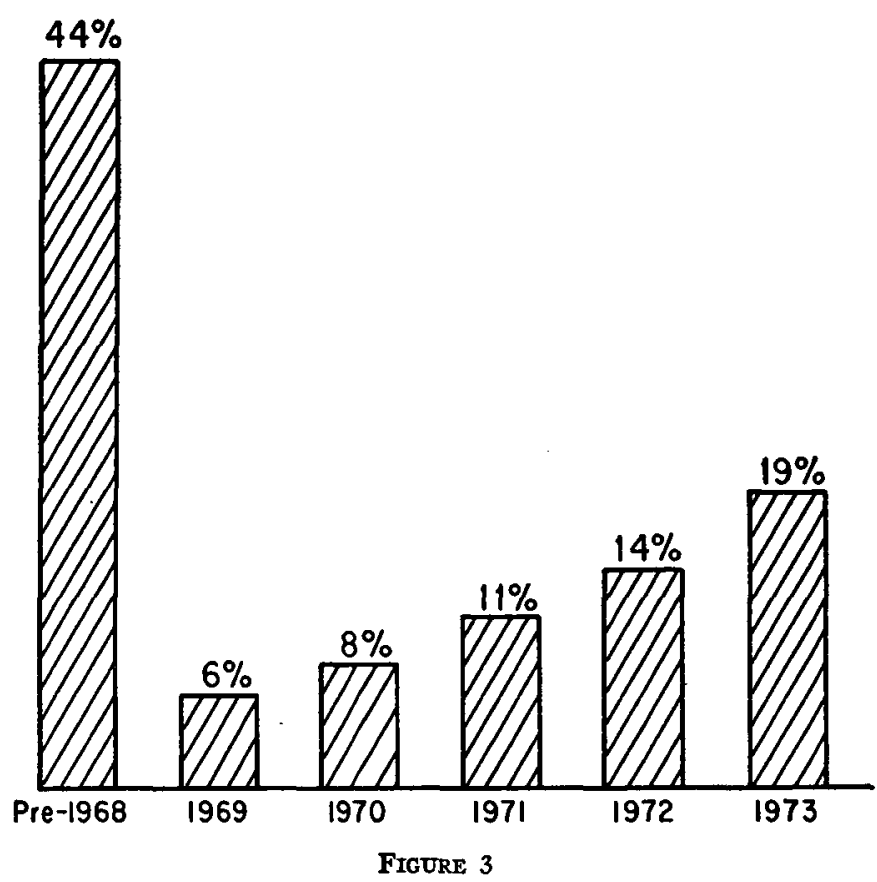

Handguns Confiscated in New York City During December 1973 by Year of OrignNal Sale

It is also true, however, that a large percentage of the handguns used in bigcity crime are new or near-new, as seen in Figure 3.

As Figure 3 shows, 19 per cent of the handguns confiscated by New York City police in December 1973 and later traced by A.T.F. had been shipped to dealers that same year. The next highest total was the 14 per cent of all guns produced in 1972, and the pattern shows a steady decline in percentage for prior years not accounted for by the fluctuations in handgun production or imports. ${ }^{181}$ If newer handguns are more "at risk" than older handguns, the number of such guns shipped in any year would be expected to have a more-than-proportional impact, up or down, on trends in gun violence.

To the extent that restricting imports reduced the rate of handgun acquisition, it may share some of the credit for moderating the upward trend in handgun violence that preceded the Gun Control Act of 1968. But there is not much credit to pass around, because the volume of handguns coming to the civilian market has increased almost to, or beyond, the 1968 peak, and the same theory that would attribute some prevention of handgun violence to the 1968 restrictions would predict further increases in handgun violence.

181 See Table 6 supra. 


\section{State Aid and Migratory Handguns}

A major aim of the Gun Control Act was to assist state and local gun control efforts by reducing the flow of guns from loose-control to tight-control jurisdictions. Prior to the Act, two northeastern states and a number of municipalities had attempted to restrict handgun possession to only those of their citizens who could demonstrate a special need to own one. ${ }^{182}$ Such laws were intended to reduce handgun ownership to a tiny fraction of the national average of 40 handguns per 100 households. As it turned out, though, municipal efforts to restrict handgun possession were vulnerable to the flow of handguns from within the state and from other states, and state efforts were vulnerable to interstate traffic. ${ }^{183}$

Whether state and local restrictive handgun licensing reduced rates of criminal violence was widely debated. States and cities with such licensing systems experienced lower rates of criminal homicide than some other jurisdictions, and guns were used in a lower percentage of all violent crime. ${ }^{184}$ But the two major laboratories of restrictive handgun licensing, New York and Massachusetts, were located in regions with traditionally low rates of handgun ownership and were demographically different from the areas to which they were compared by advocates of handgun restrictions. ${ }^{185}$

It was not contested that a major problem in administering any gun licensing system was the interstate "leakage" of guns. In the mid-1960s it was estimated that 87 per cent of all firearms used in Massachusetts crime had been purchased first in other states. ${ }^{186}$ Two thirds of a sample of handguns confiscated in New York City had come from other states, and surveys in other cities with licensing systems told roughly the same story. ${ }^{187}$

This part of the article addresses the impact of the Gun Control Act on the interstate flow of handguns. Data are presented on handgun crime in New York and Boston, two cities in which a reduction of interstate handgun traffic should result in lower rates of handgun use. A sample of handguns confiscated in New York City is then analyzed to determine where handguns are coming from after the Act, and, to the extent possible, how they are coming. A separate analysis is presented of trends in gun and nongun crime in Washington, D.C., a restrictive licensing jurisdiction where special enforcement efforts were initiated by A.T.F. in 1970.

182 N.Y. Penal Law $\$ 400.00$ (2) (McKinney 1973); Mass. Ann. Laws ch. 140, \& 131 (1972).

183 George D. Newton \& Franklin E. Zimring, supra note 2, at 91.

184 U.S. Dep't of Justice, Firearms Facts (unpublished report 1968). See George D.

Newton \& Franklin E. Zimring, supra note 2, at 123.

185 Id. at $123,181$.

186 Id. at 91.

187 lbid. See also id. at 49-50. 
1. Measuring Interstate Gun Traffic: New York and Boston. If the Gun Control Act and its enforcement has led to a reduction of interstate firearms traffic, this reduction should be evident in New York City and Boston, the principal cities in the two most restrictive handgun licensing states in the United States, because out-of-state handguns are a higher proportion of total handguns in these cities than in other metropolitan areas.

One index of the relative number of handguns in circulation is the number of violent crimes committed with handguns. Figure 4 shows the number of handgun homicides reported by the police in New York and Boston and handgun homicide trends for the 57-city sample analyzed in Figure 1. Figure 5 reports parallel data for firearms assaults-the best available measure of trends in handgun assaults.

The pattern in New York is clear: handgun homicides and firearm assaults grew steadily through the period 1966-1972. In the period 1969-1972 both homicide by handgun (up to 87 per cent) and firearm assaults (up to 70 per cent) increased three times as much as the 57-city averages (28 per cent for handgun homicide and 24 per cent for firearm assaults). Even these inflated growth rates are somewhat smaller than increases experienced during 19661969 , so it is possible that some reduction in interstate handgun traffic is concealed in the compound growth of handgun violence in New York City.

The statistics from Boston show a less steady pattern, in part because the number of crimes reported there are only 5-10 per cent of the New York City totals. During 1969-1971, handgun homicides and firearm assaults increased more than the 57-city average. There was a dip in 1972, followed by a large increase in 1973.

One needs a basis for comparison to determine whether the New York and Boston data permit an inference that the Gun Control Act is reducing interstate handgun traffic. One natural point of comparison is the pattern of handgun violence in each city before the Act. By this measure, both cities show increases in handgun violence, with a rate of increase almost as great in the years after the Act as in the years before. Another basis of comparison, used in Figures 4 and 5 , is the rate at which handgun violence was growing in other United States cities. By this index, both cities show increases more pronounced than the national urban pattern during 1969-1973. The pattern for all other United States cities may not, however, be the appropriate basis for comparison, inasmuch as both Boston and New York have traditionally had lower rates of handgun violence than other urban areas, and the very different baselines make trend comparisons misleading.

Another method of attempting to compare New York and Boston patterns would be to find cities similar to them in respects other than firearm policy. The only faintly reasonable match for New York City is Philadelphia, which has a municipal handgun policy close to New York's but a more permissive state law. And there is no adequate comparison city for Boston. 


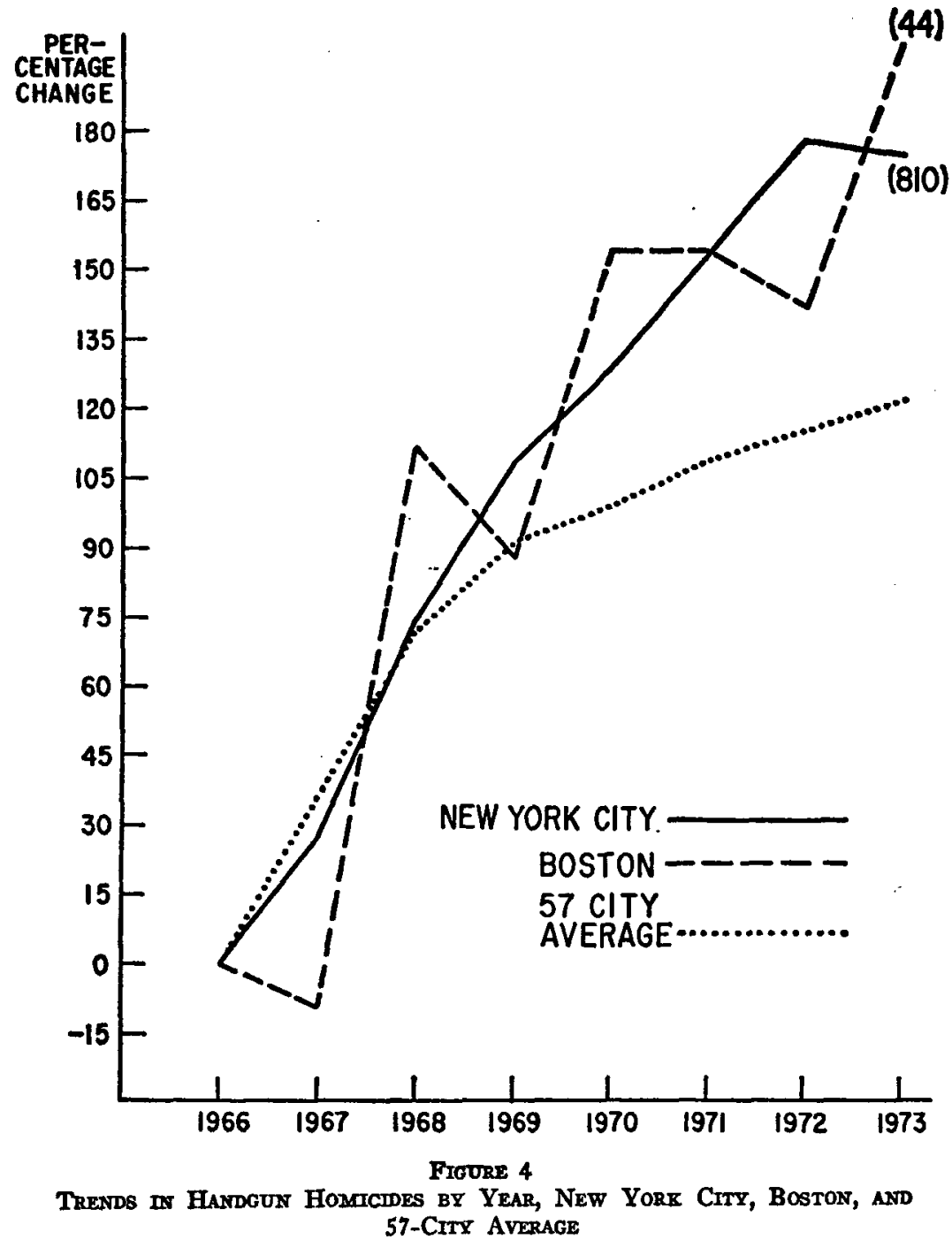

The New York-Philadelphia comparison is set out in Figures 6 and 7.

Between 1966 and 1969, New York experienced a larger increase in handgun homicide than Philadelphia (151 per cent versus 79 per cent) and a smaller relative increase in firearm assault ( 76 per cent versus 102 per cent). Between 1969 and 1972, the New York and Philadelphia patterns of increase are quite similar: handgun homicide increased 87 per cent in New York, compared to 81 per cent in Philadelphia; firearm assault increased 70 per cent in New York, compared to 80 per cent in Philadelphia. The similar trends suggest that the northeastern cities with traditionally lower rates of 


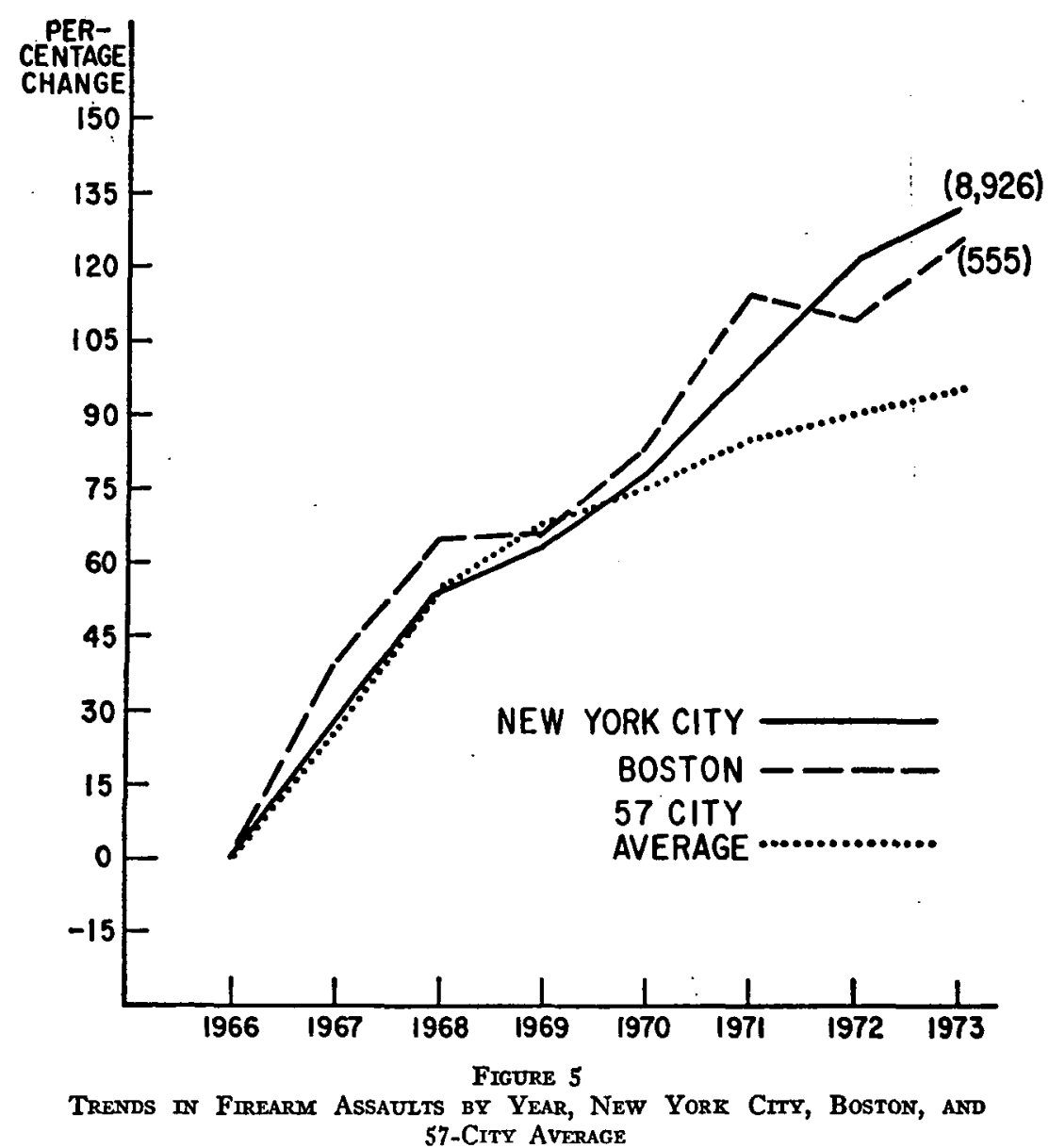

handgun ownership and use were more vulnerable to large percentage jumps in gun violence during the past few years. The similar post-Act patterns in New York and Philadelphia cannot be read as evidence that interstate handgun traffic (more important in New York violence) ${ }^{188}$ varied more significantly than other gun traffic, unless one supposes that the higher pre-Act increases in New York City handgun homicide indicate that the New York post-Act totals would have been higher still in the absence of legislation.

A further way to control for factors other than handgun supply that condition rates of violence is to compare trends in gun versus nongun crime in the cities being studied. Factors other than gun supply are assumed to affect both types of crime in a similar manner. Increased or decreased handgun 188 See Figures 6 and 7 infra. 


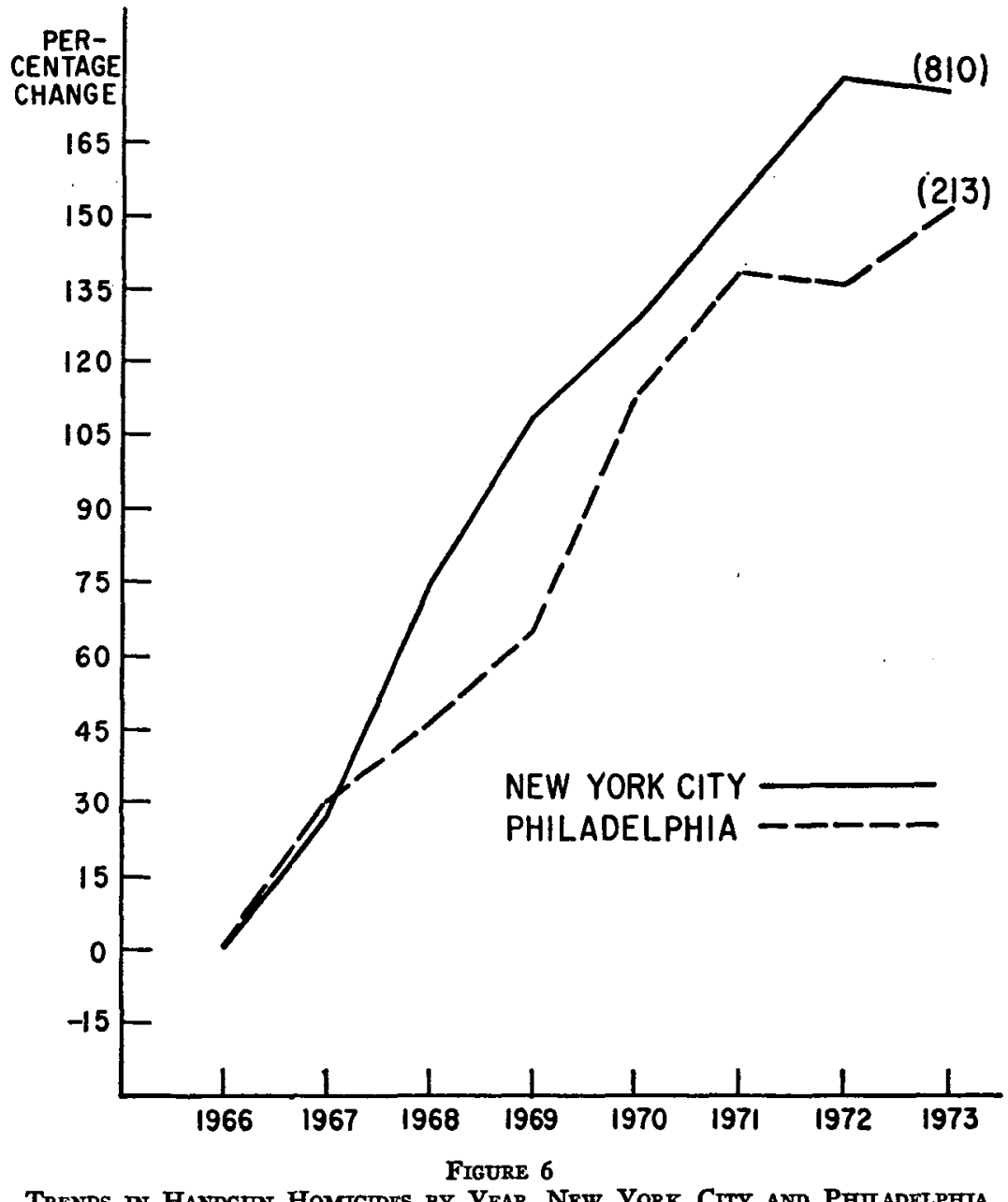

Trends in Handgun Homicides by Year, New York City and Philadellama

traffic is assumed to influence gun crime only. The percentage of crimes involving guns is a shorthand expression of trends in gun crime controlled for variations in nongun crime.

Figures 8 and 9 trend the use of handguns in homicide (Figure 8) and assault (Figure 9) for New York, Boston, and Philadelphia.

All of the individual cities in Figures 8 and 9 begin with a smaller share of homicides and assaults committed with handguns than the national urban average. Both the rate of handgun violence and the proportion of violence attributable to handguns increased more dramatically in all three cities than the national urban average. And finally while the rate of increase in the per- 


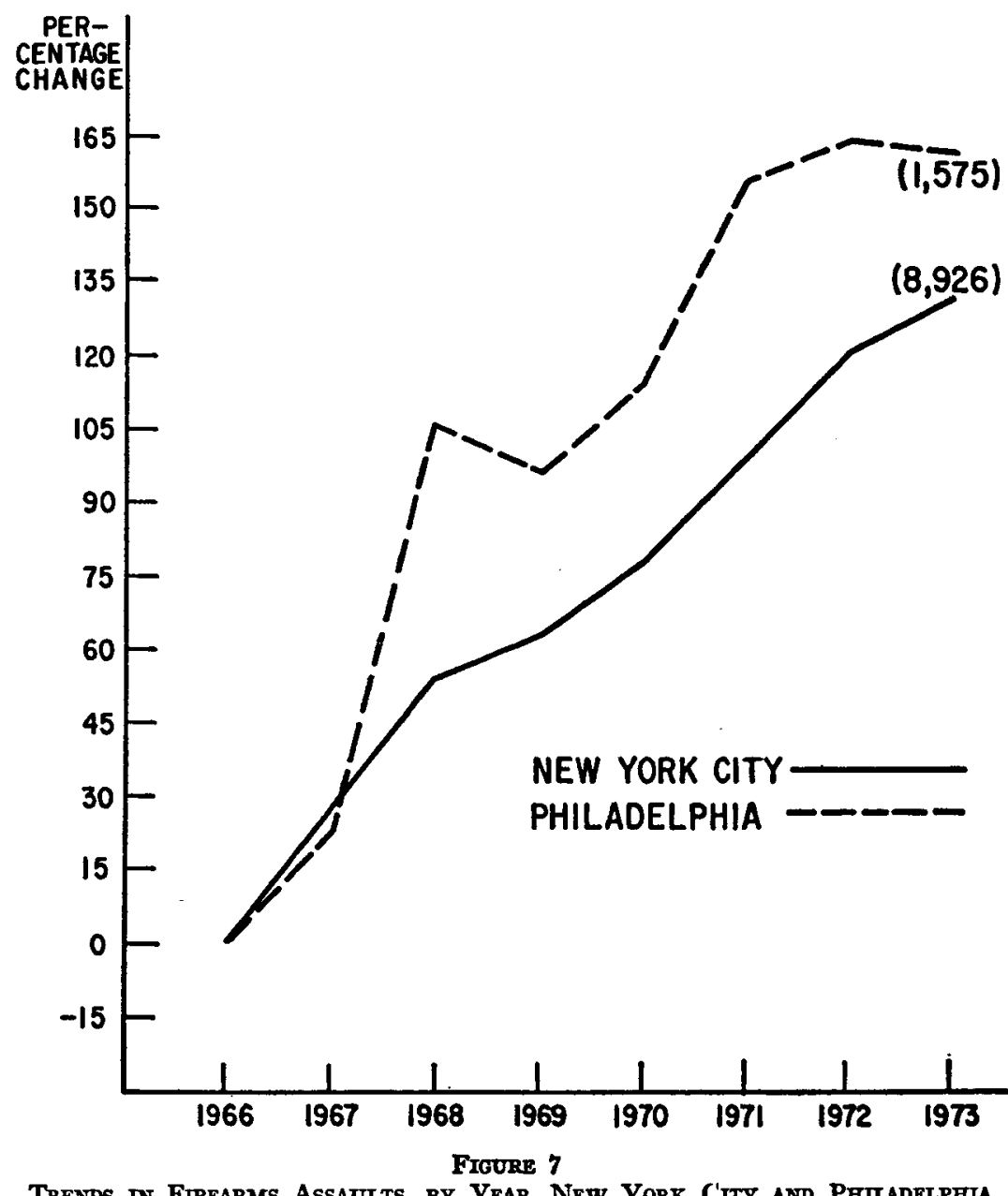

Trends in Firearms Assaults, by Year, New York City and Pemiladelpain

centage of homicides committed by handguns slows a bit in New York, the data do not support an inference that the upward trend in handgun use stabilized after the Act.

If the "new guns" hypothesis advanced earlier"189 - that the rate at which handguns are introduced into an area is disproportionately reflected in rates of handgun violence-is correct, the data suggest that the Gun Control Act of 1968 did not result in a palpable disruption of interstate handgun traffic.

An A.T.F. analysis of handguns confiscated by the New York City police provides support for this conclusion, as well as a partial explanation of why

189 See note 175 supra; see also text accompanying notes 180 and 181 supra. 


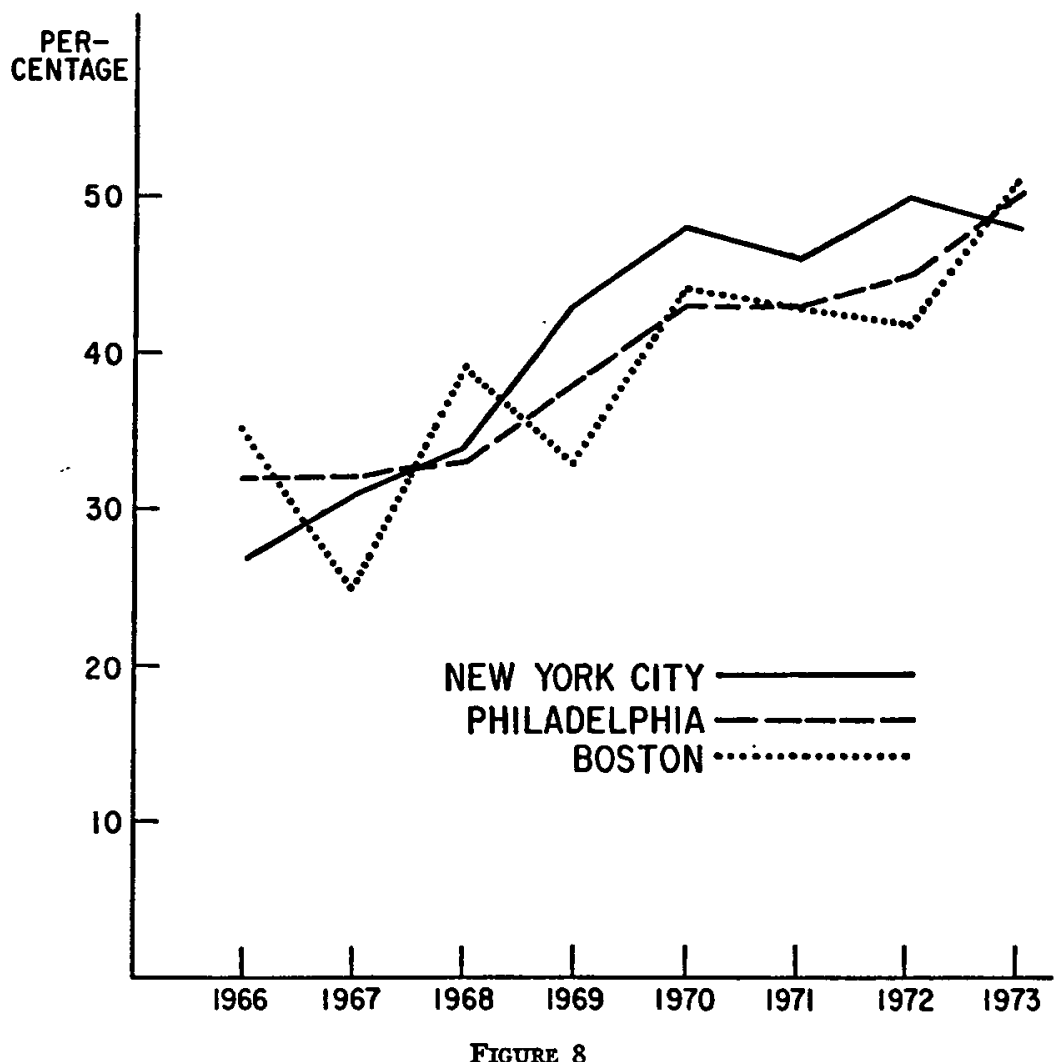

Handgun Homidie as a Percentage of Total Homicide by Year, New York City, Pemidelphia, and Boston

the Act itself had no major depressant impact on interstate handgun migration. In 1973 A.T.F. traced a sample of handguns used in crime in Atlanta, New York, Detroit, and New Orleans. Table 7 shows where the handguns confiscated in New York were originally sold by dealers.

TABLE 7

Percentage Distrabution of New York Handouns by State of Orignial Sale

\begin{tabular}{lc}
\hline \hline South Carolina & $24 \%$ \\
Florida & 13 \\
Georgia & 11 \\
Virginia & 8 \\
New York & 5 \\
All Others & $\frac{39}{100 \%} \quad$ (2048)
\end{tabular}

Sourcn: Bareau of Alcohol, Tobacco and Firearms, Project I (1974), at 8. 


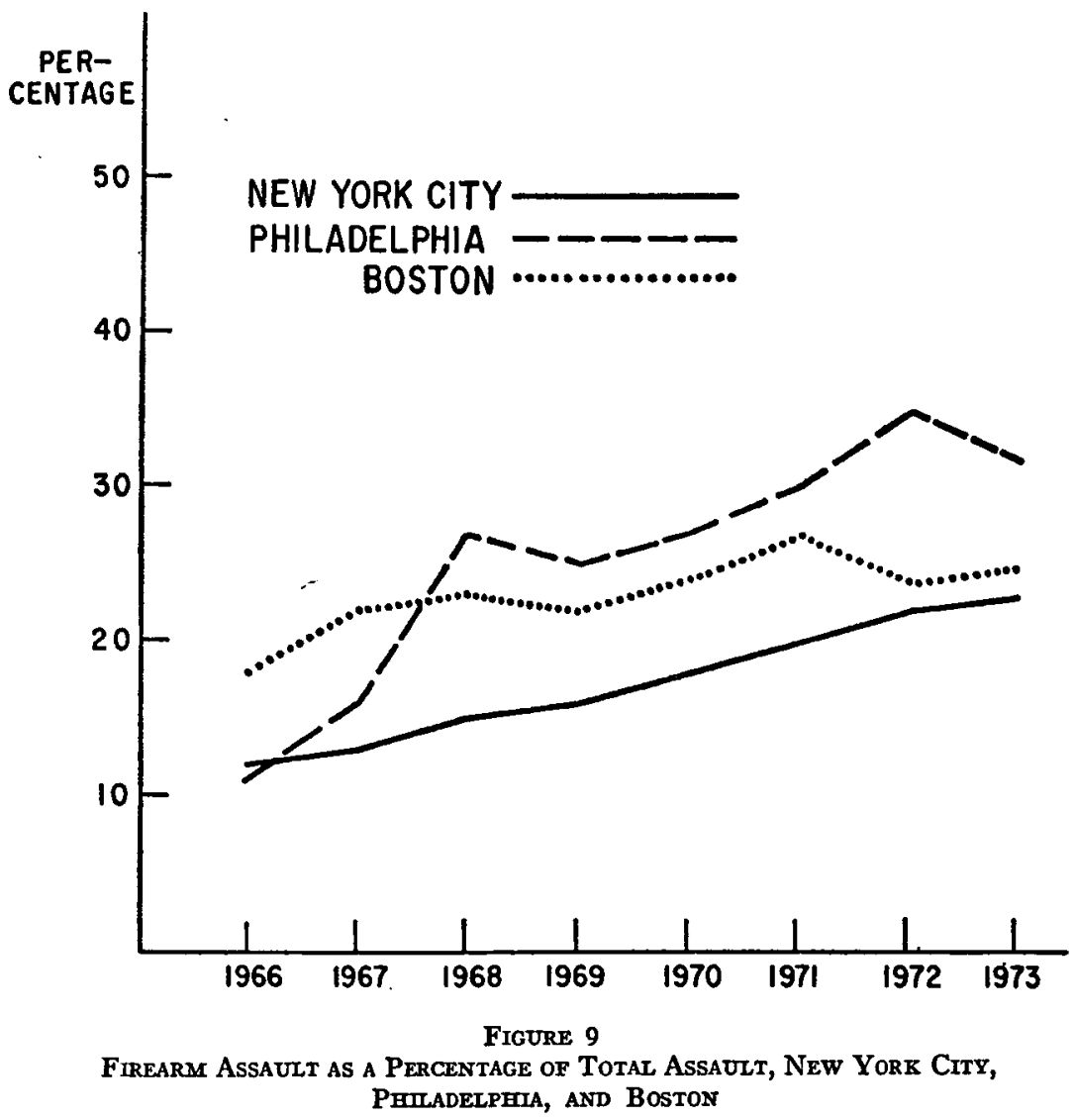

Only five per cent of the handguns traced to retail transactions were originally sold in the State of New York. Over half of all the handguns traced came from dealers in four southeastern states with high handgun populations and few controls on handgun sales. Thirty-nine per cent of the guns came from the other 45 states. The concentration of handgun traffic in a few noncontiguous states and the fact that most handguns are sold at retail in these states suggest that traffic in handguns is organized and that retail dealers are, with or without their knowledge, the prime source of supply.

Table 8 shows the distribution of a sample of New York City handguns by year of original retail sale.

More than half of the guns traced were sold at retail in the five years after the effective date of the Gun Control Act.

The A.T.F. studies have not yet traced guns in other restrictive licensing cities or attempted to show how handguns migrate from southeastern dealers 
TABLE 8

Handguns Confiscated in New York Crty durnge December of 1973 by Year of ORIGINaL Sale

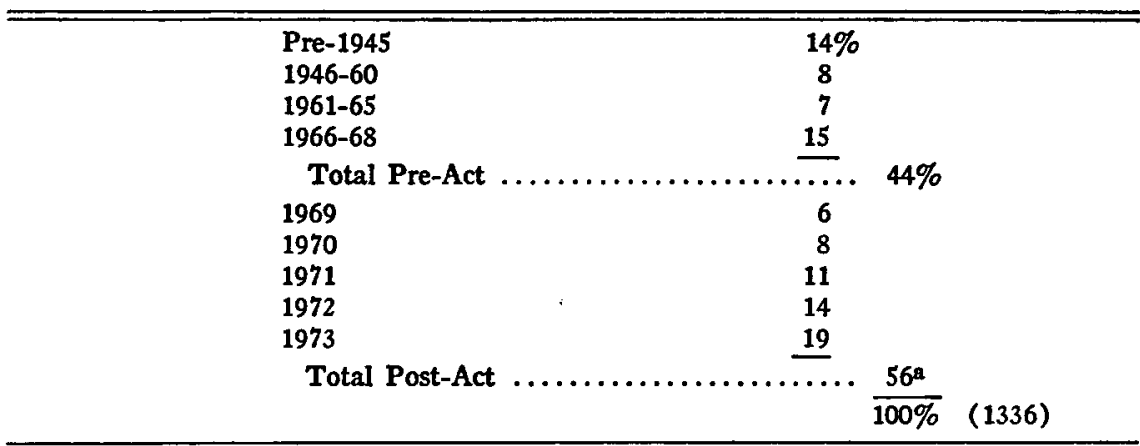

a Year totals add to $58 \%$ because of rounding.

Source: Bureau of Aloohol, Tobacco and Firearms.

to northeastern city streets in typical cases. One series of A.T.F. criminal investigations involving South Carolina dealers suggested that large-scale dealer transfers-involving more than 1000 handguns during the period of investigation-are an important source of New York City street weapons. ${ }^{100}$ In almost all of these large-scale transactions, the federally licensed dealer is a culpable party. In most of the large transactions the handguns were sold to South Carolina or North Carolina residents and apparently shipped in bulk for street sales in northern cities. ${ }^{191}$ Smaller-scale transactions-from 10 to 100 handguns-involve New York City residents coming south to purchase handguns for a return trip, and southerners buying guns for personal transport north, by means as mundane as Greyhound bus. ${ }^{192}$

If the pattern reflected in these selected cases holds true for most New York City handguns, the major mechanism for interstate transportation of handguns is the large transaction, requiring dealer participation, financing, and a distribution network in urban markets. There is danger, however, in drawing this inference from so small a sample of cases subjected to criminal investigation. A.T.F. criminal enforcement efforts are, rightly, concentrated on highvolume cases. With very scarce resources and a huge gun commerce to investigate, the sample of cases dealt with could be profoundly biased, and a large number of smaller transactions could account for a majority of interstate handgun traffic. The only way to determine the nature of interstate traffic is the detailed tracing of representative samples of urban handguns.

190 Case studies prepared by U.S. Dep't of Treasury, Bureau of Alcohol, Tobacco, and Firearms, Criminal Enforcement Division (unpublished).

191 lbid.

102 lbid. 
Yet the data already presented on gun crime and gun traffic do permit a preliminary interpretation of the impact of the Act on interstate handgun traffic. The rate of handgun crime and the proportion of attacks involving handguns have continued to increase in tight-control cities without signifcant interruption. The handguns are relatively new and come from a cluster of loose-control states. It appears that handguns are coming from the same places by the same means as before the Act. Otherwise one would expect to see a dip, followed by a recovery, in the rate at which handguns entered urban areas.

In this connection it is important to recall that the Gun Control Act requires records covering only the transfer from dealer to first customer. While it can be argued that any customer who buys thirty handguns is presumably himself a dealer, federal law does not require the dealer to notify A.T.F. of this type of transaction. If the multiple handgun buyer uses his own name, he is in jeopardy if an audit of dealer records happens to focus attention on his purchase; if the customer uses an intermediary who cannot identify him, or gives false identification, the trail of federal records immediately grows cold. The interstate transportation of guns for resale in violation of local law is a crime under the 1968 Act, as it was under the 1938 Act. But finding the offender requires a heavy investment of manpower-to audit firearm transaction records and to discover and arrest illegal sellers, principally through undercover work.

As previously noted, the manpower available for enforcing the Act has always been modest, and it is not possible to determine the proportion of A.T.F. effort devoted to suppressing interstate handgun traffic. There are thus at least two plausible explanations for the apparent failure of the Act to significantly diminish handgun migration: lack of enforcement effort and the inherent difficulty of erecting barriers between states with unlimited handgun access and those that seek to restrict handgun availability. To the extent that further manpower can produce some restraint on the interstate traffic in handguns, the state-aid approach of the Gun Control Act is not inherently unsound; to the extent that loose-control states and federally financed highways make state efforts at gun control depend on the control efforts of other states, the 1968 Act can never be expected to achieve its purpose.

2. Operation D.C. One method of testing the relative impact of enforcement effort is to invest a larger-than-usual amount of resources in a single jurisdiction and to determine the consequences of this investment on rates of handgun crime. One such experiment has been conducted by A.T.F. in a city that attempts restrictive handgun licensing and has suffered from the migration of handguns from other states. Called "Operation Disarm the Criminal," this experiment was conducted in the District of Columbia during the first six months of 1970 . The District is an admirable candidate for test- 
ing efforts to restrict interstate handgun flow because it is a tight-handguncontrol jurisdiction, bordering on two states with more lenient handgun policies. In January 1970 the A.T.F. enforcement staff in the District was increased from about seven special agents to between 35 and 50 special agents. ${ }^{103}$ This abnormally high manpower allocation was maintained for only six months and fell back to about 20 when the Internal Revenue Service declined to provide funds for a one-year extension of the project. The enforcement effort, at a ratio of one agent to about 2000 population, was about ten times greater than A.T.F. manpower in other major cities. ${ }^{194}$

The special agents assigned to Operation D.C. contacted dealers in the District and proximate areas in Maryland and Virginia that were the major source of handgun supply to Washington. But the principal occupation of these agents was "street work"- undercover investigations, efforts to purchase guns from illegal sellers, and attempts to perfect federal gun law charges against persons whom the local police nominated as being particularly troublesome.

Any attempt to measure the consequences of this effort runs into a number of obstacles. Operation D.C. was identified as a candidate for study long after its conclusion, and the historical records are incomplete. The experiment lasted only six months, which means that any impact on handgun migration attributable to the effort would probably be short-lived. And because the best measures of trends in gun migration are crime statistics, short-term changes in the flow of handguns might not result in discernible differences. Further, this was one of many simultaneous crime-control efforts occurring in the District, and care must be taken to avoid crediting the operation with results that justly should be attributed to other variables. Also, the rate of handgun violence had increased rapidly prior to 1970, and there is danger that regression from abnormally high prior levels of handgun violence might be misread as evidence of enforcement impact.

There are a number of ways in which the special enforcement efforts of Operation D.C. might have reduced the migration of handguns into the District of Columbia and the supply of such weapons available in the District. First, enforcement activities result in the confiscation of weapons, which are thereafter unavailable for sale or criminal use. Project records indicate that just over $\mathbf{5 7 5}$ weapons were confiscated or purchased during the six months the operation was near full strength, an average of about 30 guns per agent

193 Memorandum from Charles R. Peterson, Assistant Regional Commissioner, Bureau of Alcohol, Tobacco and Firearms, Mid-Atlantic Regional Office re: Operation Disarm the Criminal, at 1 (August 6, 1970).

194 Compare the Peterson memorandum, id. at 1, with Stephen D. Brill, How Guns Get to Town: Tracing the Southern Connection, New York [Magazine], April 8, 1974, at 42 (reporting 63 agents spending about half of their time on firearms enforcement in New York City, with ten times the population of Washington, D.C.). 
man-year, and a total too small to generate hope that this process alone had a measurable impact on rate of gun violence. However, the operation also involved efforts to persuade gun dealers in nearby out-of-state counties to monitor their customers more carefully. ${ }^{195}$ While data on handgun sales by these dealers are not available, it is possible that the influx of weapons into the District was substantially reduced. The enforcement effort might also have disrupted the sale of weapons within the District by deterring or apprehending illegal firearms sellers. The project reported a total of 159 criminal cases initiated but did not estimate how many of the subjects apprehended were involved in large-scale commerce in weapons. ${ }^{196}$

The most straightforward method of testing the manifold effects of special firearms enforcement efforts is to examine trends in gun crime within the District, on the assumption that a substantial reduction in the number of handguns entering the District would result in a lower number of gun crimes than would otherwise be expected. Figure 10 shows trends in handgun and all other homicide in the District of Columbia by year for the period 19661973.

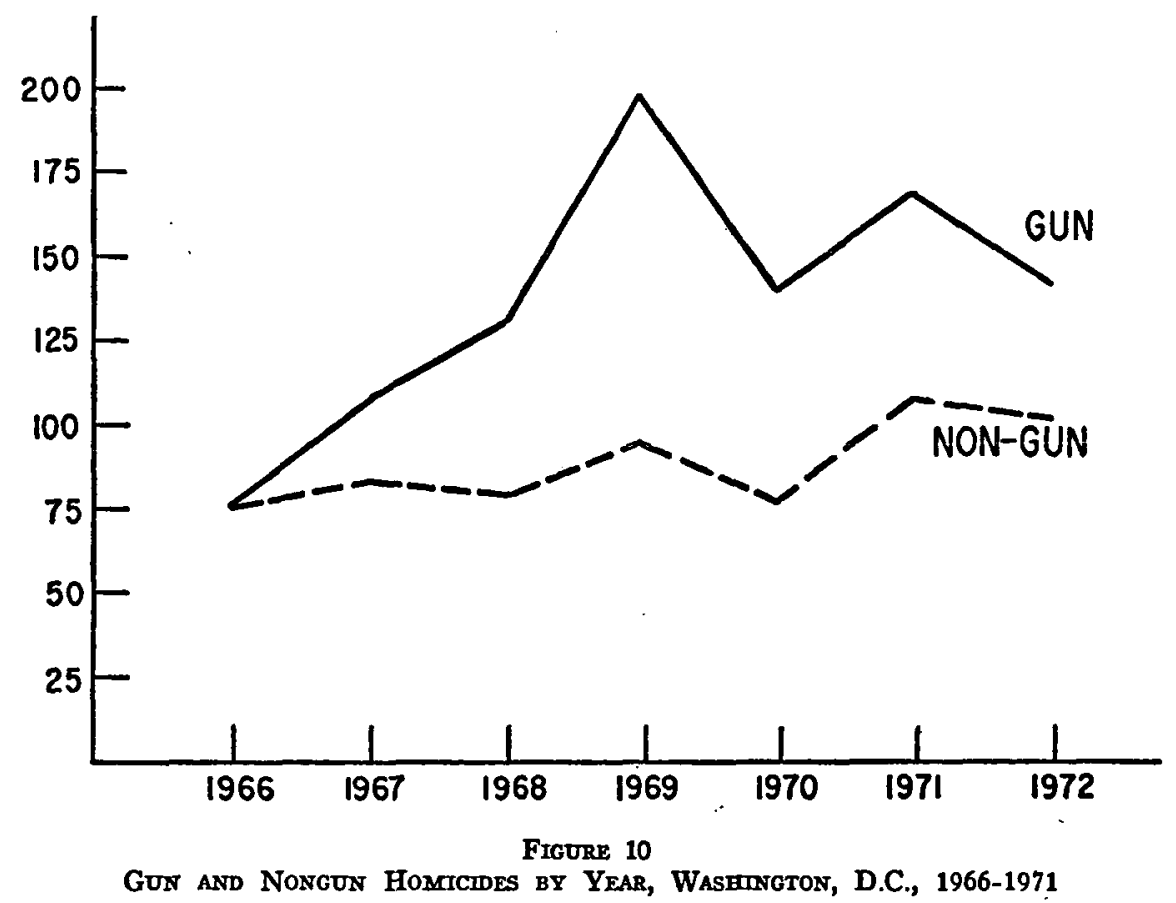

185 Charles R. Peterson, supra note 190 , at 3.

106 Id. at 2. 
As Figure 10 shows, both gun and nongun homicide declined in 1970, but the rate of gun killings did not decline disproportionately. With the cooperation of the Washington D.C. police, we obtained a monthly breakdown of gun and nongun homicides from 1966 through December 1971.197 These supplementary data were acquired because the intensive enforcement was of short duration, and monthly data would allow the use of interrupted timeseries analysis. Figure 11 shows the monthly patterns of gun and nongun homicide.

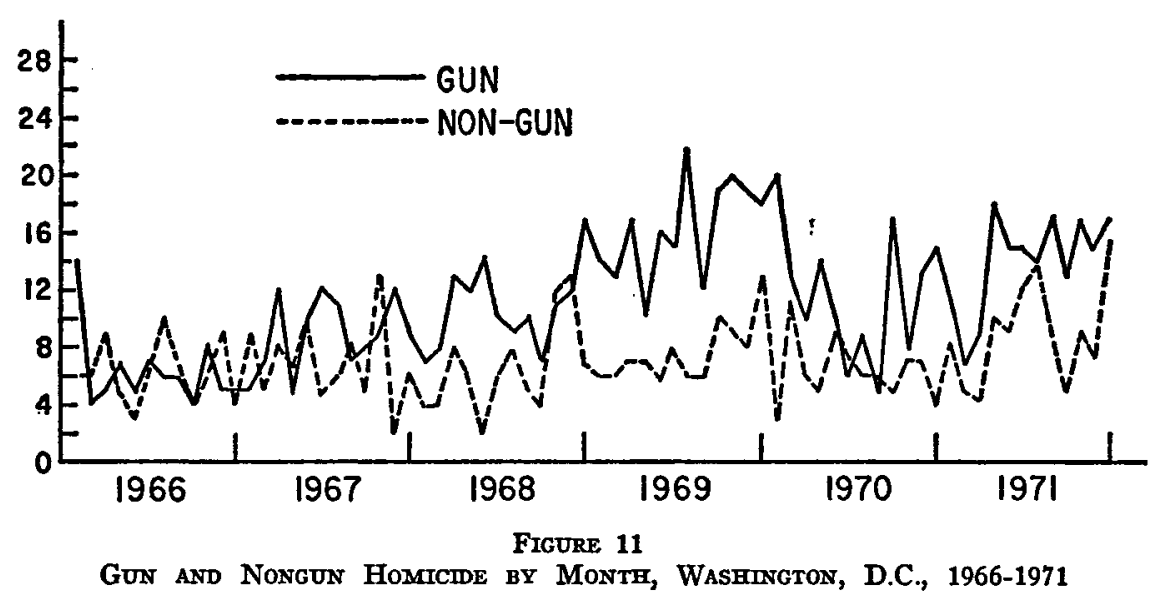

What appears visually is a drop in gun homicides in the middle months of 1970 that is not present in the nongun pattern. The interrupted time-series analysis indicates that gun killings decreased substantially during the enforcement effort while nongun killings did not. The time series of nongun killings reveals no significant change in the rate or trend in homicides. ${ }^{198}$ Gun homicides, using February 1970 as the first month in which an effect would be

197 The monthly data were originally provided by Chief Jerald Wilson's office. When subsequent checks with homicide records revealed a number of months where the Chief's figures and the Homicide Unit figures diverged; the planning department of the police force audited the 1969, 1970 and 1971 monthly reports. The figures for the thirty-six observations during these years are not the same as reported to the FBI, although the deviations are relatively minor. Also, justifiable homicides have been deleted from these months.

198 The nongun killing series had 49 pre-intervention observations and 23 post-intervention observations based on an assumption that February 1970 is the first "post" observation. The estimated change in level is an additional .99 killings per month, which is not significant at the $<.05$ level $(T=1.36$, significant at $<.10$, with 68 degrees of freedom). Nongun killings were also run assuming delays in enforcement impact of three and seven months, respectively, with no significant change in the volume of killings noted.

Figure 12 presents a graphic representation of the nongun series. 


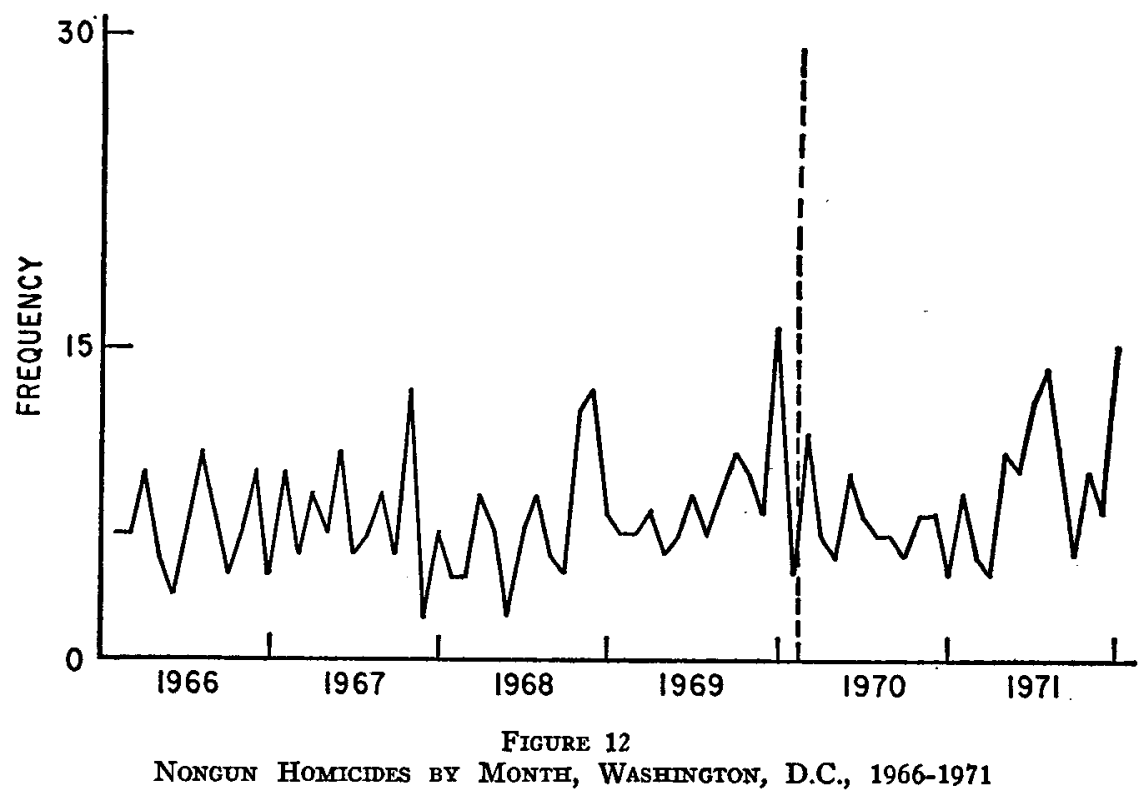

expected, decline in subsequent months. ${ }^{199}$ While the program used for the analysis is not well suited to studying the impact of enforcement efforts, the results in this case suggest some short-term enforcement effect and this suggestion is confirmed by use of a second program more suited to studying enforcement effect. ${ }^{200}$

The data on aggravated assault tell a different story. Monthly assault data were not available covering months prior to 1969 . Figure 14 provides yearly data on Washington assaults since 1966, and Figure 15 gives quarterly data for assaults from 1969 through 1973.

Gun assaults do not decline, while nongun assaults fluctuate in a pattern

199 The gun-killing series had the same 49 pre-intervention months and 23 post-intervention months, based on February 1970 as the first "post" observation. The estimated change in level is a reduction of 8.59 killings per month $(T=-3.14$, significant at $<.005$ with 68 degrees of freedom.)

Figure 13 presents a graphic representation.

200 The problem with using standard time-series programs is that enforcement programs might have an accretive impact on gun supplies. Since our outcome measure is directed to handgun scarcity, it is to be expected that the enforcement effort will lead to greater scarcity after two months than one, and the model of impact should be cumulative. Indeed, if the major impact of Operation D.C. was putting gun traffickers out of business by arrest, and if arrest kept the trafficker out of circulation for six months, the impact of the program should be six times as great after six months as after one.

After the initial analysis had been performed, Professor Gene V. Glass of the University of Colorado performed a time series analysis of the Washington data using a program which postulated the impact of the campaign accretively, as a gradual reduction in gun killings to reflect the cumulative impact of the campaign on gun scarcity. The model 

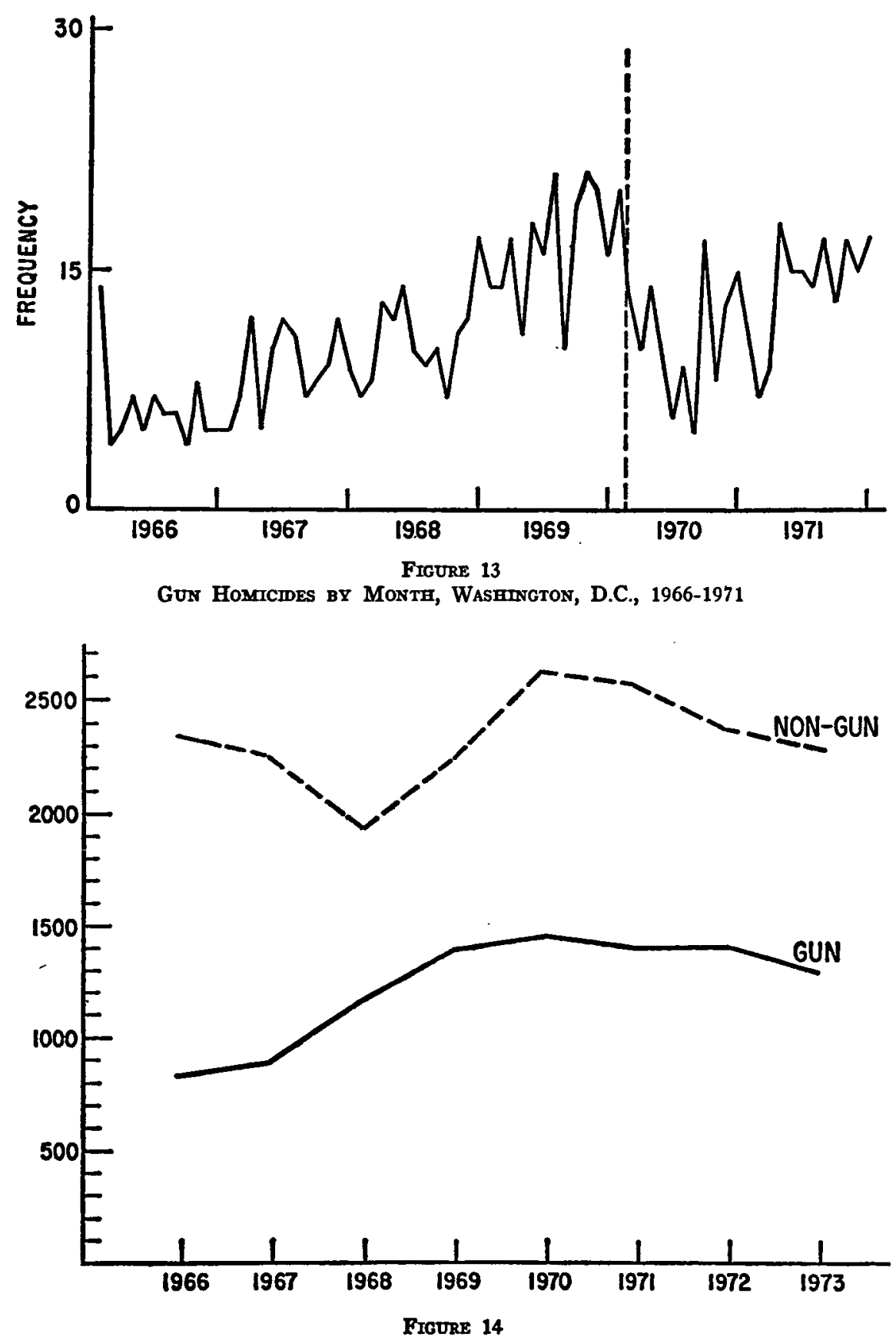

Gun and Nongun Assautts by Year, Wasmongtor, D.C., 1966-1973 


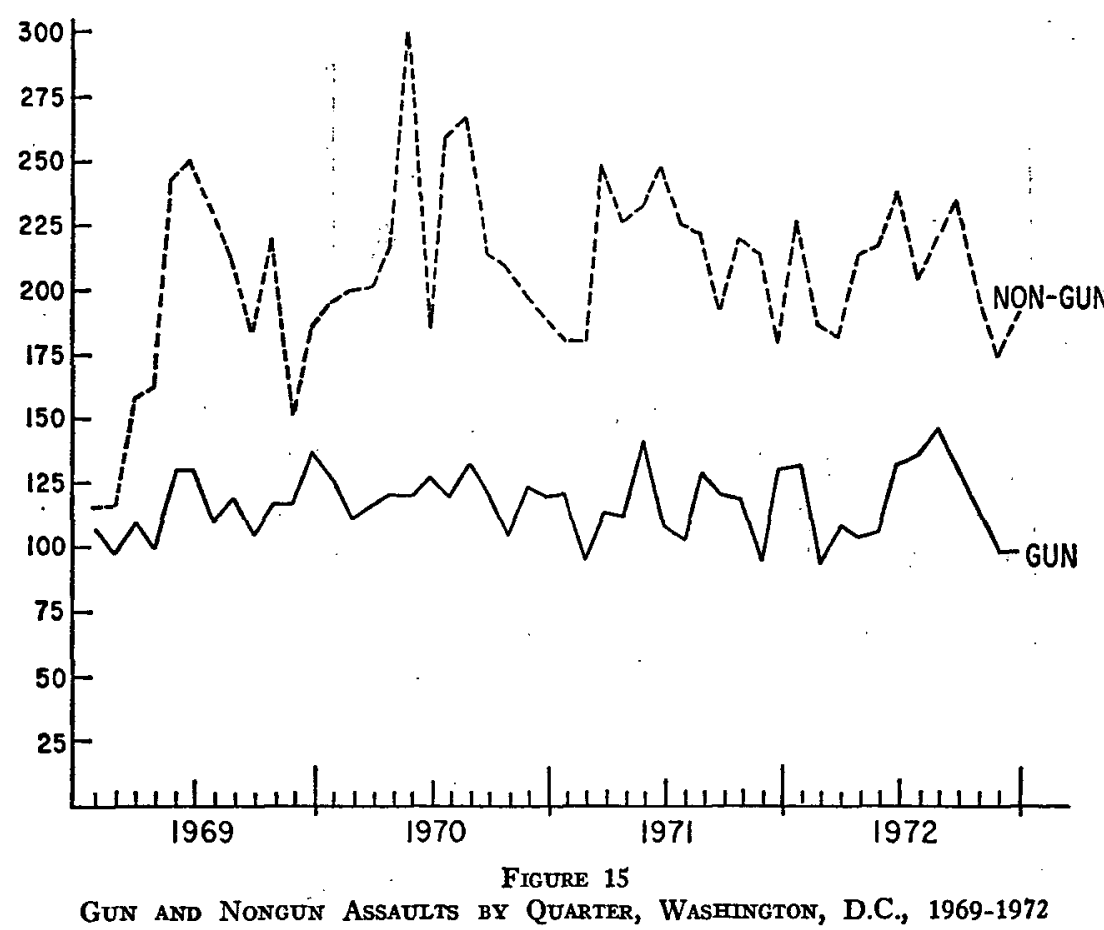

unrelated to enforcement. On a yearly basis the flat 1970 performance appears encouraging, since gun assaults had been increasing steadily prior to 1970 . However, with insufficient data to perform a time-series analysis and with no dip in the level of gun assaults similar to the mid-1970 dip in gun killings, the assault data do not support the hypothesis that Operation D.C. substantially affected the migration of handguns into the District of Columbia.

Taken as a whole, the data on Operation D.C. suggest that special enforcement efforts might produce measurable impact on gun crime. But the undramatic data on assaults and the brevity of the experiment leave uncomfortably ample room for debate on whether such an exercise can produce results worth its costs.

predicted the following proportions of full impact by month for the program on gun killings in 1970.

$\begin{array}{lc}\text { Jan. } & 0 \\ \text { Feb. } & 1 / 6 \\ \text { March } & 2 / 6 \\ \text { April } & 3 / 6 \\ \text { May } & 4 / 6 \\ \text { June } & 5 / 6\end{array}$

\begin{tabular}{ll} 
July & $6 / 6$ \\
Aug. & $5 / 6$ \\
Sept. & $5 / 6$ \\
Oct. & $4 / 6$ \\
Nov. & $3 / 6$ \\
Dec. &. \\
\hline
\end{tabular}

Succeeding months predicted a drop-off of $1 / 6$ in effectiveness every two months. This "slow drop" model is a slightly better fit to the data than the model used in note 199 supra, with a $T$ value of 3.52 , with 70 degrees of freedom. 
In sum, on the available data, the Gun Control Act has not produced any measurable change in the migration of handguns from loose-control to tightcontrol jurisdictions. It appears that the interstate movement of handguns into tight-control areas was not interrupted by the Act because the 1968 scheme of records and regulation did not inhibit large-scale purchases from dealers in loose-control jurisdictions for interstate transportation to northeastern city streets. A.T.F.'s single experiment with concentrated enforcement produced suggestive but not conclusive evidence of impact. It is unknown to what extent the difficulty of the task as opposed to the absence of sufficient manpower is the explanation for the lack of measurable impact of the Act on interstate handgun migration.

It is also difficult to speak with confidence of the inherent difficulties of the Act's state-aid approach because many remediable difficulties have hampered the enforcement of the "state-aid" sections of the Act. Thus far, A.T.F. has been operating with (1) an insufficient information base for allocating enforcement resources, (2) lack of coordination between regulatory and criminal enforcement efforts, (3) regulations that fall far short of the power delegated by the Act to suppress interstate handgun migration, and (4) a manpowerallocation policy that spreads a thin coat of inadequate resources nationwide. Each of these problems deserves further elaboration.

Although some progress has been made during the past year, A.T.F. still lacks much of the information it needs to plan enforcement policy, and allocate criminal enforcement resources, rationally. Before mid-1972 the Bureau did not require any information from manufacturers on the number of guns they produced. At present, this information is collected on a quarterly basis, but no data are available on the number of firearms sold in specific regions, either at retail or wholesale, and there is no way that regulatory manpower can be allocated according to variations in patterns of firearm traffic. Lack of basic data has also hampered criminal enforcement efforts. High or disproportionate volume of handgun sales in a particular state is a clear indication that the state is a launching pad for interstate handguns. Data on handgun sales could also prove useful in monitoring changes in points of origin for guns transported in violation of the Act. Criminal enforcement efforts have also been hampered by lack of information on who is transporting handguns in violation of the Act and how the guns get from loose-control to tight-control states. Project " $I$ " is the Bureau's first venture toward gathering these necessary data, but that operation has not yet traced a representative sample of handguns confiscated in tight-control cities beyond the point of first retail sale. ${ }^{201}$

201 An effort to do this as part of Project I, phase 2, has been planned by the Bureau. However, the manpower cost of tracing beyond first purchase has prevented any district office from implementing the trace. 
Related to insufficient data is the apparent lack of coordination between the regulatory and criminal enforcement segments of administration of the Act. Even though much of the regulatory work required under the Act has been performed by Special Agents with arrest powers, there has not been sufficient use of regulatory powers to facilitate criminal enforcement ends. Millions of forms giving details of gun transactions lie fallow in dealer record books. The decentralized nature of these records and limited manpower make a complete audit of these transfer records impossible. Yet a careful sampling of regulatory enforcement records can show what types of transactions, customers, and locations are most closely associated with criminal violations of the Act.

An example of the use of regulatory data to set both regulatory and criminal enforcement priorities comes from an analysis we conducted of 100 dealercompliance investigations in the Chicago district office of A.T.F. As part of the compliance investigation, records of individual transactions were selected by the inspector and verified as to the purchaser's address and criminal record. Some transactions are chosen by the inspector at random, some are chosen because the purchaser's address appeared to be in a high-crime area, and some because more than one gun was purchased. A number of analyses can be performed with this sample of purchase records. Table 9 shows the percentage of apparent violations of the Act found in the audit.

More than half of all multiple firearm purchases involving handguns appeared to violate the Act, compared with a one-per cent estimated violation rate of transactions selected at random. From all appearances, regulatory audits should concentrate on multiple handgun transactions, and the criminal enforcement branch has a special stake in acquiring information on the number and pattern of such transactions.

This is only one example of how coordinated sampling of firearms trans-

TABLE 9

Rates of Apparent Law Vtolation

\begin{tabular}{lcccc}
\hline & \multicolumn{3}{c}{ Reason for Verification } \\
\cline { 2 - 5 } & At Random & $\begin{array}{c}\text { High-Crime } \\
\text { Area }\end{array}$ & $\begin{array}{c}\text { Multiple } \\
\text { Weapons }\end{array}$ & Total \\
\hline $\begin{array}{l}\text { Firearm(s) Purchased } \\
\text { Handguns } \\
\text { All Others }\end{array}$ & $2 \%$ & $7 \%$ & $58 \%$ & $10 \% \%^{\mathrm{a}}(\mathrm{N}=370)$ \\
& 0 & $2 \%$ & 0 & $1 \%$ (N=141) \\
\cline { 2 - 5 } & $1 \%$ & $7 \%$ & $50 \%$ & 511 \\
\hline
\end{tabular}

- Includes 15 cases that could not be classified.

Source: U.S. Treasury Dep't, Bureau of Alcohol, Tobacco and Firearms Records. 
actions can aid in isolating enforcement priorities and in producing data on the extent to which the law is being observed. The regulatory branch could also follow up on transactions in a sample of cases to see how many guns in particular areas are no longer traceable to a local owner after one year. The criminal enforcement unit could trace confiscated big-city handguns from first purchasers as far forward in the chain of commerce as is possible. This would provide information on how interstate movement occurs and suggest ways in which the record-keeping and information systems presently used might be altered to depress the present rate of interstate handgun migration.

It is true that the decentralized nature of transaction information makes the gathering of intelligence both difficult and expensive. But much of the problem could be solved by new regulations within the powers granted under the Act. Requiring dealers to keep records of sales by type of gun is a normal and far from onerous duty of a federally licensed business. Requiring dealers to notify A.T.F. of multiple retail handgun sales is justified, either because of the high risk that the recipient is acting as an unlicensed dealer or because such guns are more frequently shipped out of state in violation of the Act. ${ }^{202}$ A requirement that dealers verify local residence beyond inspecting identification documents would be a harder issue under the Act but could be defended on a variety of grounds.

To criticize A.T.F. for spreading its manpower too thinly is something of a shot in the dark, if only because the Bureau does not have the information on which such a judgment can be based. It is known that "state aid" was a high priority of the 1968 Act, and it is likely that far fewer than 30 per cent of all prosecutions under the Act concern interstate shipment of handguns and long guns. The total agent staff in New York City was estimated at 63 last year, which appears low in relation to New York City's dominant role as a receiver of interstate handguns. But without knowing where guns are sold, how they come to tight-control states, and how effective various strategies are in reducing interstate flow, it is difficult to criticize a pattern of manpower allocation; it is equally difficult to formulate a rational allocation without such data.

With respect to the state-aid aims of the Gun Control Act, it is not possible to determine whether interstate migration of guns continues because the approach of the Act is hopeless or whether lack of strategic intelligence and enforcement manpower are a major source of the difficulty. There is every indication that we had better find out soon. Political support for a more extensive federal role in firearms regulation is difficult to measure or predict.

\footnotetext{
202 Rex Davis, the director of the Bureau, has announced his intention to draft a regulation requiring dealers to notify the Bureau of multiple handgun sales, but no regulation had been drafted at the time this article went to press.
} 
But changes in federal law, if they occur, will either take the form of attempts to strengthen the present state-aid system or will scrap the approach in favor of a national control system, either licensing owners or limiting production. It would thus seem appropriate to test the preventive potential of intensive enforcement of the ban on migratory weapons.

At the same time, a nationwide expansion of enforcement large enough to test the impact of manpower would be expensive and impractical in the near future. A.T.F. has a limited number of special agents and the lead time necessary to train more agents is substantial. Further, the type of federal police work necessary for the detection of black-market firearms sales has a high component of "street work" - and a large expansion of this element of the Bureau's work raises the specter of a national police force. More likely, any attempt to spread an increase in enforcement power over too wide an area would result in insignificant increases in the Bureau's ability to enforce the law.

The appropriate next step is a sustained effort to increase enforcement in one or two major tight-control jurisdictions. Depending on available resources and police cooperation, Washington, Boston, or New York would seem to be admirable candidates for such a study. The data from the New York handgun analysis by Project I would implicate South Carolina, North Carolina, and Florida as sending areas worthy of special enforcement and regulatory efforts. A fair test would involve a tripling of enforcement and regulatory manpower over at least a two-year period.

These comments are based in the premise that the state-aid sections of the Gun Control Act were intended as a mechanism to reduce the flow of firearms into states and cities attempting to restrict gun ownership. It is, of course, possible that Congress did not place a high priority on that aim but adopted state aid as an ideological compromise. If so, the compromise may have worked admirably without any sign of reductions in firearms violence and the administration of the Act by A.T.F. has been, if anything, too energetic.

\section{Concluding Reflections}

The present study was intended both as an investigation of the impact of a single piece of legislation and as an attempt to gain perspective on larger issues relating to guns, gun controls, and the legislative process. This section addresses a few of these larger issues. In doing so, I will often venture opinions that are not rigorously supported by existing data.

Without doubt, the role of firearms in American violence is much greater in 1975 than in 1968. Rates of gun violence and the proportion of violent acts that are committed by guns have increased substantially since the Gun Control Act went into effect. Behind these increases lies the probability that 
handgun ownership has become at least a subcultural institution in the big cities which are the main arena of American violence. During this period, regional differences in gun ownership and use have been moderated as the large northeastern cities that were traditionally areas of low ownership and use have experienced large increases in handgun use.

The special role of the handgun in urban violence is one of the more obvious lessons of the data we have assembled. For many purposes it seems more appropriate to divide recent fluctuations in homicide and assault into "handgun" and "other" categories than to speak of homicide rates as an aggregate-since 1966, rates of handgun homicide have increased more than three times as much as homicides by all other means.

The data gathered in the present effort suggest, but do not compel, two other conclusions about patterns of handgun ownership and violence in the United States. First, the sharp rise in the proportion of violence attributable to handguns in northeastern cities may lead to modification of the hypothesis that general patterns of handgun ownership determine the extent to which handguns are used in violent episodes. While it is still true that those regions with the highest general levels of gun ownership have the highest proportion of gun use in violence, the past decade has produced an increase in handgun use in the Northeast that leaves cities in that region closer to but still below the national average handgun share of violence. This could be due to a substantial rise in handgun ownership in the general population in these cities, but that would mean that a vast northeastern urban handgun arsenal has been accumulating during the past ten years. It is more likely that handgun ownership increased substantially among subcultural groups disproportionately associated with violence without necessarily affecting other parts of the population. It is, to give a concrete example, neither necessary nor likely that gun ownership among middle-class New York Jews (other than small merchants) has increased dramatically in the past decade as New York handgun homicide has increased.

If one adopts a "subcultural" explanation of the relationship between gun ownership and violence, hypotheses about the effect of increases or decreases in handgun ownership on handgun violence should take a slightly more complicated form. One would predict that high levels of handgun ownership produce high levels of handgun violence for two reasons: more handguns are available at a moment of perceived need and high ownership rates necessarily suggest high levels of handgun availability to all potential consumers. Low general levels of handgun ownership, on the other hand, become the necessary but not sufficient condition of low levels of handgun violence. If the lowerthan-average general ownership levels are still high enough to create relatively easy handgun availability, and if both handgun ownership and propensity for violence are concentrated in discrete subpopulations, lower-than-average gen- 
eral ownership is an inadequate insurance policy against increases in handgun violence. It is only when ownership levels are low enough to have an impact on handgun availability that low aggregate ownership will depress handgun involvement in rates of subcultural violence.

A second tentative implication of this study-somewhat more directly inferred from the data-is the so-called "new guns" hypothesis discussed earlier. For reasons that have not yet been adequately explored, new handguns are involved in crime at higher rates than older handguns. This may be of importance in designing firearms control strategies and also suggests need for further refining hypotheses about the relationship between general levels of handgun ownership and the rate of handgun use in crime. In urban settings where new handguns are available these guns are purchased by persons who plan to use them. Older handguns include a large number that are packed away in attics or kept in homes for self-protection. Such weapons show up in crimes or confiscations only if used by their owners or transferred by sale or theft to other individuals. One would thus expect a smaller proportion of older guns to be confiscated. As long as the chances of transfer are relatively small, each new handgun will have much more impact on handgun availability than each older gun owned by the civilian population. As long as the average person who wants to buy a handgun this month is more likely to misuse it than the average person who already owns one, handgun availability will have more impact on trends in violence than handgun ownership.

What have we learned about the role of the federal government in gun control? The data presented in these pages cannot show that a particular strategy of firearms control is appropriate for the future, for that is an issue that requires value determinations as well as empirical data. The data do suggest, however, that any further initiatives in gun control should be focused on handguns. There is also, in the history of the administration of the Act, an intriguing contrast between what I would call "gatekeeping" and policing strategies of federal control. Whatever went wrong with the prohibition on imported "Saturday Night Specials," enforcing the ban was clean white-collar work of a type normally undertaken by federal regulatory agencies. Attempts to keep handguns away from criminals and outside the borders of tightcontrol jurisdictions require more police work. In this effort the role of A.T.F. is best compared with the narcotics enforcement efforts of the federal government.

Efforts to limit handgun supply on a national basis, by limiting legitimate production, or imports, or both, will not require a large federal street police force. At the point when market controls make illicit gun production profitable, some police work will obviously be needed, along the lines of controls on illicit liquor production.

Any federal control strategy that seeks to regulate firearms possession with- 
out regulating production and imports requires more policing, both because the number of guns will remain large and because keeping guns out of the hands of subclasses of the population is extraordinarily difficult when guns are freely available to others.

There is, however, one important difference between the criminal enforcement of federal narcotics laws and present federal gun laws: virtually all guns that come into illegitimate hands come from the legitimate market. For this reason, records kept by dealers may provide criminal enforcement agents with an information base that is not present in narcotics control. But as long as transaction records are decentralized and limited to first purchases, this advantage is of limited importance.

Data from the first five years after the Gun Control Act are a poor source of information on the consequences of handgun scarcity, because handguns have not been scarce. Thus, the extent to which handgun use would be replaced by long guns and the use of "homemade" weapons in crime cannot be tested by examining the impact of the 1968 Act. It is also important to note that the relatively small proportion of violence attributed to older handguns in New York City does not mean that older guns will not be a more serious problem if the flow of new handguns is interrupted. If production and imports are interrupted, the primary source of handguns would be the existing civilian inventory. The pressure to acquire guns would drive up the price of older guns, creating incentives for both owners and prospective burglars that increase the chances that old handguns will be transferred to new owners. Again, however, experience since 1968 gives no basis on which to estimate the extent or consequences of this tendency.

Thus, studying the impact of the Gun Control Act gives only limited insight into the consequences of more restrictive federal gun control policies. I am also convinced that the legislative history of both the 1968 and 1938 Acts tell us little about the shape of future federal gun control efforts. It is possible (vide the Federal Firearms Act of 1938) that the Gun Control Act of 1968 will be controlling federal law into the next century. But political sentiments about firearms control may prove more fluid than some commentators believe. It is only if the firearms issue remains as unimportant as it has been to date that one can predict future legislative behavior from prior congressional action.

Whatever the future holds, the federal Congress is unprepared to make intelligent policy choices concerning the federal role in firearms regulation. The Bureau of Alcohol, Tobacco, and Firearms, with all its faults, has an informational monopoly on firearms regulation. No committee of the Congress has paid sustained attention to the administration of the Act, or prodded the Bureau toward producing the kind of information that is needed for intelligent planning. With sporadic exceptions, those members of Congress 
that introduce new firearms proposals are failing to obtain or use available information. In the near future any real reform in the administration of the Act will have to be internally generated by the Bureau. If Congress is supposed to be the policy-setting institution, the Gun Control Act of 1968 may stand as an example of the blind leading the halt. 